\title{
Sidney Dawes and the McGill Museum of Canadian Art
}

by Norma Morgan

McGill has an extensive art collection which for one bundred years consisted largely of portraits. Sidney Dawes wanted McGill to have an art gallery and offered to give the University a group of paintings that would form a nucleus of an art collection. McGill still does not have an art gallery but it did receive sixty-four Canadian paintings from Dawes. The collection bas grown since that time to include more than eleven hundred works. The article includes a complete catalogue of the Dawes donation.

$M c G i l l$ possède une riche collection d'ceuvres d'art. Pendant un siècle, celle-ci se composait essentiellement de portraits. Sidney Dawes voulait que McGill ait un musée des beaux-arts, ce qui explique qu'il ait fait don à l'Université d'un groupe de tableaux qui devaient former le noyau de sa collection. McGill n'a toujours pas de musée des beaux-arts mais a effectivement hérité de soixante-quatre tableaux canadiens de Dawes. Cette collection a pris de l'ampleur depuis cette époque et elle comporte aujourd'bui plus de 1100 tableaux. L'article se termine par un catalogue complet du don de Dawes.

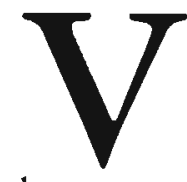
ery few people are aware that McGill University owns an extensive art collection that embellishes libraries, student and faculty lounges, offices and residences of the University. It is also not well known that some of the more important works of the collection were given to the University by one man with a specific purpose - to create an art gallery at McGill.

McGill has acquired works of art since its foundation and it is largely the result of the generosity of benefactors, graduates and friends that the collection is such a large and splendid one. During its first hundred years, McGill collected portraits commemorating leading figures in the history of the University (usually paid for by subscription or donated by the subject), and a limited number of paintings, prints and reproductions given to the residences by graduating classes or purchased by the Warden's Fund at Royal Victoria College. ${ }^{1}$

In 1962, Sidney Dawes (1888-1968) a leading Montreal industrialist and a graduate of
McGill (B.Sc. '10) offered to purchase and present to the University a number of traditional Canadian paintings as a nucleus for an art gallery. ${ }^{2}$ It was his intention that his gift, together with the early Canadian sketches and paintings in the McCord collection would "...be a historical collection of worthwhile Canadian painters right up to the present time." $\mathrm{He}$ wanted the gallery to be located in the Student Union building on Sherbrooke Street which would be available when the Student Union moved to its new location on McTavish Street.

Chancellor R. E. Powell supported Dawes' suggestion. Powell had recently been informed by F. R. Scott that a friend of his, Arnold Wainwright, had an important collection of Krieghoff paintings that he was prepared to bequeath to McGill if the University could promise to provide suitable space to hang the collection.' Powell was anxious to assure Wainwright that the Student Union would be converted into a museum and that his paintings would hang there. ${ }^{6}$

Powell had already discussed the future use of the Union Building with the Principal, F. 


\section{Sidney Dawes and the McGill Museum of Canadian Art}

Cyril James, who agreed in principle. ${ }^{7}$ At a meeting of the Board of Governors on the 15 October 1962:

The Chancellor reported that there
is a possibility of the University
being given a collection of Canadian
Paintings if there be a suitable place
to display them and he also pointed
out the necessity of moving the
McCord Museum shortly. On his
recommendation it was moved, sec-
onded and resolved that an
Architect be appointed at a fee not
to exceed $\$ 1,000$ to make a prelim-
inary survey and estimate the cost of
conversion of the old Student
Union Building on Sherbrooke
Street to provide suitable quarters
for these and other exhibits of the
McGill Museums.

Powell then asked Sidney Dawes, who was in the construction business, to form a feasibility committee with Galt Durnford as architect. ${ }^{2}$ One month later, at the opening of an exhibition entitled Everyman's Canada at the McCord Museum, Principal James announced that the Museum would move to the Student Union site on Sherbrooke Street. ${ }^{10}$

Dawes was delighted and enthusiastically began to make plans for the new art gallery. He was interested in attracting additional collections such as Wainwright's Krieghoffs and he and Powell began to identify owners of private collections who might be approached for donations. " He apparently expected to make some sort of arrangement with the Montreal Museum of Fine Arts (MMFA) for the loan or gift of paintings. Dawes arranged a meeting with Colonel Hugh Wallis, President, and Evan Turner, Director, of the MMFA to visit the Union site ${ }^{12}$ and later told the University Museums Committee that important material from the Museum "would become available" to a new art museum at McGill. "Dawes discussed with Powell the possibility of asking Alan Jarvis, recently retired Director of the National Art Gallery of Canada to act "... in an advisory capacity, such as helping us to collect Canadian paintings, speaking to the students about Art..." He also interested himself in the administration of the new gallery.
He and Dean F. K. Hare, a member of his committee, brought a candidate to Montreal from Regina to be interviewed for the position of Director of the new gallery, proposing that he might initially teach in the Art History Department. ${ }^{15}$

Sidney Dawes wrote to Powell: “...most Universities have Art History Museums of their own comprising numerous collections and it is high time that McGill started one also." ${ }^{16}$ This was Dawes' major goal and he pursued it with vigour and tenacity.

The University Museums Committee also greeted with enthusiasm Principal James' announcement that the McCord Museum would move to the Student Union. It had for some time proposed that the McCord Museum which had been closed since 1936 and was housed in a building about to be demolished, and the Ethnological Collection, closed in 1939 , be combined and a new site found for them. The Student Union building was well situated for this purpose. An analysis of space requirements made by the Museum staff showed that the combined collections would effectively use all the space available at the Student Union site. Dawes argued, however, that the property was too valuable to use for storage; that it should be used for exhibition and lecture rooms and additional material should be stored elsewhere. When it became clear to the University Museums Committee that Dawes and Powell were proposing that the McCord Museum become primarily an art gallery the Committee responded with an official statement of its position. ${ }^{17}$ Professor Fried expressed the feeling of many of the Museums Committee members when he said that:

The University should give no thought to creation of yet another museum unit until its existing collections could be made available for teaching purposes... One must take a practical view of related costs including additional salaries, maintenance of the collections, and supplementary museum activities over the coming years. ${ }^{18}$

Dawes and Powell had not understood that the Museums Committee's plans would not 


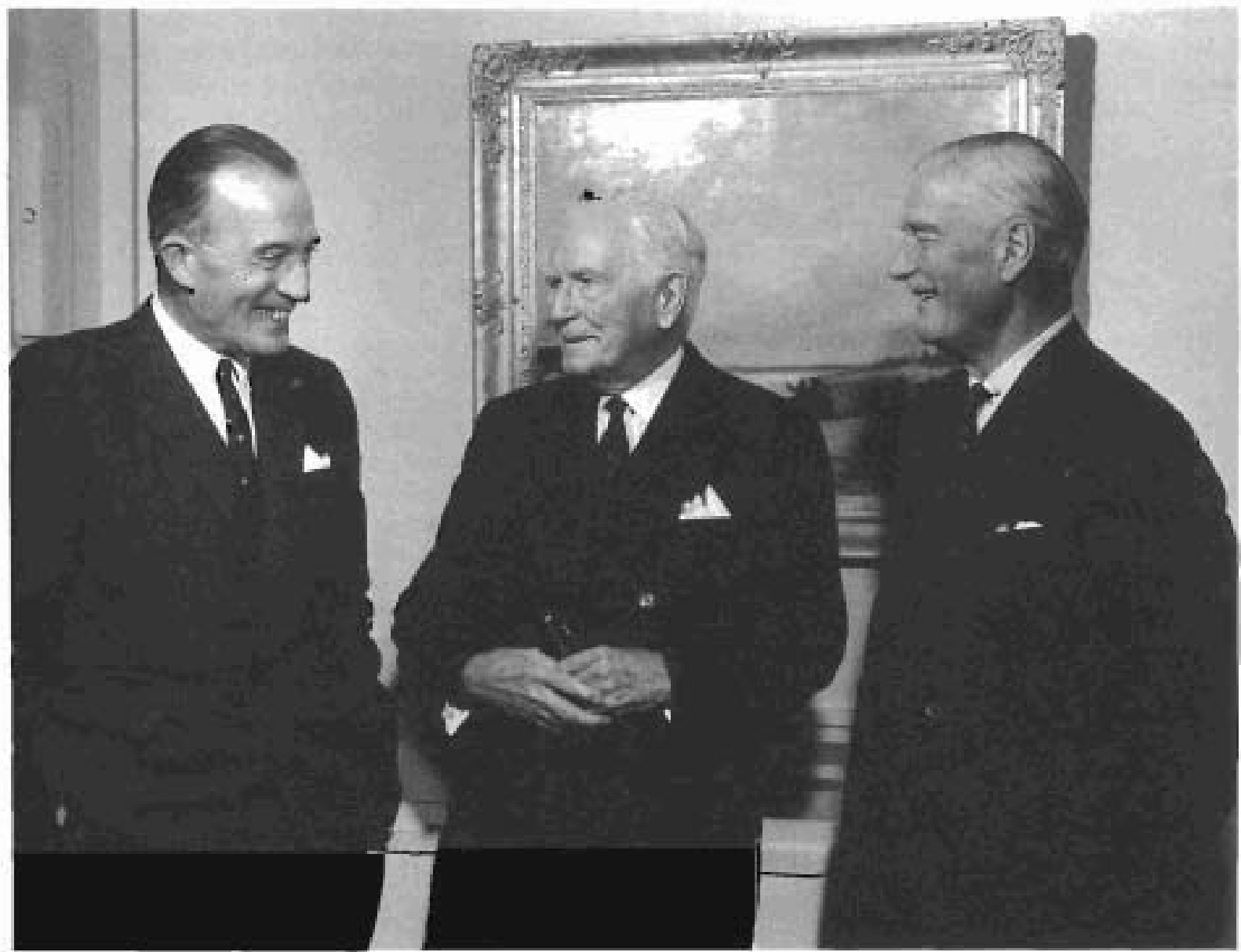

Figure 1. Principal F. Cyril James, Arnold Wainwright and A. Sidney Dawes.

accommodate the concept of combining an art gallery with the McCord Museum. As the Museum had been closed for so many years it is perhaps not surprising that the Chancellor misunderstood the McCord's role as a museum of Canadian History. At a meeting of the University Museums Committee, the Chancellor noted that the McCord's recent exhibition, "...Everyman's Canada, obviously an art exhibit, had misled bim into thinking that the Museum policy was veering away from a museum of objects towards an art gallery." The Committee explained that the exhibition displayed only one aspect of the collection. However, the McCord would be grateful for a gift of paintings, "...as long as the subject matter falls within the scope of the historical collections." 20

When Alice Johannsen, Director of McGill University Museums learned that Dawes had already purchased several paintings which he intended to give to the University, she wrote an urgent letter to Chancellor Powell, delivered to his home:

After all the discussions and correspondence with the University Museums Committee it must be plain that the university Museums have worked out policies and prior- 


\section{Sidney Dawes and the McGill Museum of Canadian Art}

ities through many years and that a University Museum of Fine Arts has no immediate place in these plans until after such time as our urgent need for space for the McCord and Ethnological Collections can be met.

I sincerely hope that some means may be found for the University to accept Mr. Dawes' generous offer without compromising the future of the McCord and Ethnological Museums, and allow these paintings to be seen under suirable safety restrictions in residences and other University buildings. ${ }^{21}$

Johannsen also pointed out that important donors "...have emphatically expressed...that they might substantially increase their support of the McGill Museums' cause if they could be assured that the Union site would be turned over to the McCord and Ethnological Museums."22

There was no support for an art gallery from the Department of Art History either. The history of Canadian art was not taught at McGill at that time. The Chairman, W.O. Judkins, "...did not contemplate teaching anything in Canadian art before 1967, if then." 23 It is not surprising then that he was not interested in hiring the prospective Director to teach in his department as he felt that the candidate's qualifications were to teach only history and criticism of North American Art. ${ }^{24}$ The Chairman of the Department of Art History told the Museums Committee that a McGill art gallery would be an unnecessary luxury, and that the MMFA could provide any necessary facilities. ${ }^{25}$

Meanwhile Rocke Robertson, who had just replaced James as Principal in December, attempted to mediate between Dawes' eagerness to establish an art gallery and the Museum Committee's reluctance to share space in the Union building with a collection of paintings. Robertson asked F. K. Hare, Dean of Arts and Science to consider “...setting up picture displays in the New Arts Building..." explaining to the Chancellor that it "...would be the best way to ensure that students saw fine pictures. ${ }^{26}$ After consultation with all of the interested parties, Robertson sent a memorandum to Powell concerning the Student Union Building and the Museum. In it he explained that there was a good possibility that the Student Union would be used to house the McCord and Ethnological Museums and that he had "...suggested to the Senate Development Committee that they consider seriously setting up a building behind the Union and connected to the Union to house such things as the Faculty of Music, other art collections, etc." He continued:

I would recommend (a) that we express our extreme gratitute to $\mathrm{Mr}$. Dawes and assure him that we are very keen to possess the pictures that he has shown us (the fifteen or so Canadian paintings); (b) we should tell him that these pictures will greatly increase the value of our collection of Canadiana and that we can readily house them; (c) we ought to explain to him that we are not yet in a position to plan a general Art Gallery but that if the McCord Museum is to be placed in the Students' Union we would like to name one of the galleries after him and, (d) we should ask him to slow down on his approach to potential donors until such time as our plans are more clear cut. ${ }^{27}$

In spite of Robertson's recommendation, neither Powell nor Dawes seemed to have understood that an art gallery would not be a major part of the McCord Museum. In February the candidate who had been interviewed for the position of Director of the art gallery informed Dawes that he had accepted a position at another university. Powell noted in a memorandum that "Dawes also thinks that the man would be glad to come to McGill when we are ready for him, probably two years hence." 28 Dawes wrote to the candidate:

As soon as the old Union building has been converted into the McGill Museum of Art they will require a Director who will also lecture and I can assure you that they will approve a salary for both positions 


\section{Sidney Dawes and the McGill Musenm of Canadian Art}

\author{
of $\$ 8,000$ per annum plus a free \\ apartment in the Museum. ${ }^{\text {" }}$
}

Copies of the letter went to Dean Hare and to Principal Robertson who naturally felt that Dawes had no right to take for granted that the old Union Building would be converted into the "McGill Museum of Art." He wrote Powell that a decision had not been reached and that although most of the space would be required for the McCord and Ethnological collections "...it is still very possible that there will be room for the pictures that Mr. Dawes originally planned to give to the University." He felt that Dawes was moving too rapidly. He was "...trying to force on us a full blown Museum of art. The only solution that I can see is to build an additional building but we are not nearly ready to decide the need for this. ${ }^{* 10}$ Powell replied a month later (he had been on vacation), "Apparently I got a bear by the tail when I responded to his apparent eagerness to do something for the University."

During this exchange of letters, Dawes was purchasing paintings to give to McGill, and had written the University stating his intention to make his first donation of eight Canadian paintings and two Group of Seven sketches. It was at this point that a compromise was reached, negotiated by J. H. Holton, Secretary of the Board of Governors. Dawes would give paintings to McGill University agreeing that he would "...not insist that the pictures, if accepted, remain with the McCord Collection at all times but may be from time to time exhibited in public spaces in various buildings." 32 The University Museums Committee was statisfied that the paintings "...should be accepted in the name of the University, not in the name of the McCord Museum. In this way they could be placed at the disposal of the Museum as occasion warranted, without compromising the position of the Museum with respect to the creation of a Museum of Fine Art at McGill."

Nevertheless Dawes appeared to expect that there would eventually be an art gallery at McGill. He continued to purchase paintings suitabie for the collection as he envisioned it and actively explored different avenues to accomplish his goal of a gallery. With the donation of the first group of paintings he stated that "The dates of these paintings range from 1871 to 1930 and they will be 'a nucleus' of paintings to start a History of Art Collection commencing with the McCord prints to the present time." ${ }^{\text {st }}$ A month later he wrote, "The Gagnon and Coburn paintings fit well into any Canadian History of Art Collection, which I hope McGIll will one day have."3s"

Dawes was also eager to help to raise funds for the conversion of the Union building. He telephoned the Chairman of the Canada Council and learned that "...a donation towards the formation of a McGill Art History Museum on a 50/50 basis would come within the purposes for which The Canada Council was formed." He asked Powell to write or authorize him to do so."

When she learned of Dawes' intentions, Alice Johannsen, Chairman of the McGill Museums wrote the Principal that she "...was alarmed to learn...that, despite all our previous efforts at restraint, Mr. Sidney Dawes is actively and privately negoriating for a Canada Council grant 'to enable McGill to renovare the old Union as an Art History Museum."

Powell, on the other hand was concerned with soothing his potential donors. He wrote Robertson:

As you probably realize, I think I need to do something to pacify Sidney Dawes, Arnold W $W_{\text {ain wright }}$ and Frank Scott, referring to their eagerness to have McGill become the owner of valuable pictures and books. If something can't be done, they will probably lose interest and so will I."

At the same time another potential donor wrote the Principal asking to meet him to "...discuss the possibility of building a collection of Canadian art at the University." 15 Although completely unrelated to Dawes' and Powell's proposals he also apparently advocated the "...eventual construction of a new University Art Museum." ${ }^{60}$ A meeting was arranged between the donor, Alice Johannsen, Professor Maxwell J. Dunbar, Chairman of the University Museums Committee and Professor W. O. Judkins, 


\section{Sidney Dawes and the McGill Museum of Canadian Art}

Chairman of the Department of Art History. After this meeting Judkins, who was an American and had very definite and rather restricted views as to the role of his department, wrote a lengthy memorandum to the Principal: "The Department of Fine Arts (Art History), in relation to the problem of a University Fine Arts Museum." In it he pointed out that a gallery might tend to entice family bequests, and as "...Canadian art in the antiquarian sense (if not the aesthetic) already falls within the province of the McCord Museum, ...that there might be some merit in the idea of a small gallery housed within an enlarged McCord Museum." He believed however, that "...for the pursuit of Art Historical studies a Fine Arts Museum is of only partial value, and if the collections are restricted to Canadian and/or Contemporary art, the benefits are almost negligible." He stated that "...the proposal of a new University Art Museum should be emphatically declined."

Several months later, Powell wrote the Principal that Dawes was continuing to buy pictures for McGill and asked if the University would take possession of some of them. He believed that Dawes still hoped "...that places will be provided in new buildings." 42 Robertson asked the Libraries' Committee to consider displaying the paintings in the libraries. The members of the Committee concurred in the proposal with one exception, and agreed to see that they were always appropriately displayed while not binding themselves to display them in the Redpath Library permanently.

In January of 1964 the Senate Development Committee "...reached its decision to recommend that the former Students' Union Building should be assigned as the home of the McCord Museum." 44 Records do not reveal any further correspondence concerning an art gallery at McGill.

Powell continued to be concerned about the Dawes and Wainwright gifts, writing to the Principal every few months reminding him that suitable places should be found to display pictures. Although he was still a member of the Board of Governors, he had retired as Chancellor in May 1964. He wrote the Principal in October that, "Although I'd like to extricate myself, I think my obligations to Mr. Wainwright and Mr. Dawes will continue to keep me interested if not a bit involved." "4s He asked the Principal if there could be a committee to determine the location of Dawes' paintings and possibly rotate them. The principal was quick to act. Russell Harper had just been appointed Chief Curator of the McCord Museum and Robertson asked him with Professors Judkins and John Bland to form a committee. ${ }^{46}$ Dawes admired Harper and subsequently consulted with him concerning some of his purchases for McGill.

The McCord Museum opened in the Student Union Building in March 1971. Arnold Wainwright bequeathed twenty-two Krieghoff paintings to the University which are in the McCord Museum. Dawes continued to purchase and give paintings to the University until 1967, the year before his death. He gave in all sixty-four paintings dated from 1863 to 1963 by thirty-three Canadian artists. All of the works donated by Dawes were purchased specifically to give to McGill. ${ }^{47}$ Dawes with his chauffeur delivered many of the paintings himself and his chauffeur often hung them. A few were accepted by the McCord Museum but most were originally hung in libraries and in Divinity Hall.

In 1971, after a number of the Dawes paintings were moved out of the libraries, Professor R. Melzack of the Psycholngy Department suggested to the Visual Arts Sub-Committee (which had been formed in 1967) that the Dawes paintings should be collected, catalogued and displayed together. This was accomplished ${ }^{48}$ and an exhibition of twentyone of them was held in the libraries in 1972.

Sidney Dawes was a dynamic and aggressive business man with a history of active commitment to his community. Born in Lachine in 1888 , he was the grandson of the founder of one of the major breweries in the Montreal area. He graduated from McGill in 1910 with a Bachelor of Science degree in Engineering. ${ }^{49}$ He served in the Royal Canadian Artillery in the first World War and was awarded the Military Cross. After the war he became President of Atlas Construction Company, one of the foremost Canadian contruction companies, responsible for many major power devel- 


\section{Sidney Dawes and the McGill Museum of Canadian Art}

opments, aqueducts, bridges and tunnels, in eastern Canada. Dawes was a man with a powerful personality and enormous energy which he also turned to many endeavours outside his business career. He was an active participant and administrator in the sports field, serving on the Canadian associations of Lawn Tennis and Amateur Skiing, the latter as president. He founded and became the first President of the Canadian Olympic Association and was the Canadian member of the International Olympic Committee. He served on the Board of Trade and the Protestant School Commission. In the arts, he was an active member of and important donor to the Montreal Museum of Fine Arts. He served on the Acquisition Committee for Canadian Art from 1953 to 1962, the latter four years as chairman. He began giving paintings to the MMFA in 1940, giving at least one and as many as ten each year for the next ten years. During the fifties he gave six more paintings. His final donation was in 1961, the year before he became interested in the gallery at McGill. All of the paintings donated by Dawes to the MMFA were by Canadian artists, all from Quebec with the exception of four major paintings by Tom Thomson. ${ }^{50} \mathrm{He}$ also accumulated an extensive personal collection of works by Canadian artists which included six works by J. W. Morrice and several by Robert Pilot who was married to his niece. The entire collection was bequeathed to his family.

As Powell wrote, Dawes, Wainwright and Scott were eager to have McGill become the owner of pictures and books, but Dawes may have been partly motivated by the fact that he had had a falling our with the MMFA. ${ }^{51}$ As chairman of the Acquisitions Committee at the MMFA, his relatively conservative views conflicted with the more "modern" taste of the new Director, Evan Turner. Dawes believed that Canadian art was not really valued sufficiently by Canadians and was disturbed that the paintings he had given the MMFA were not being hung. He wanted to establish a gallery of traditional Canadian art, a subject he felt was not sufficiently covered by the MMFA.

Regardless of his motives, Dawes gave a remarkable collection of Canadian paintings to
McGill. The collection reflects his bias towards traditional art and completely ignores the schools that emerged in the nineteen forties after the publication of the Refus Global. His donation included a painting by each member of the Group of Seven including four by McGill's own Arthur Lismer, paintings by twenty different Quebec artists, works by Casson and Milne among others from Ontario and two works by Emily Carr.

The University still does not have an art gallery, but had there been one it is very likely that due to the space constraints found in most galleries, many of Dawes' paintings would have been collecting dust in storage much of the time. As it evolved, almost all of his paintings except those in the McCord collection are hanging in locations where they can be enjoyed by the whole University community - faculty, students and visitors, having the exposure that he would have wished.

The gift of the Dawes Collection in the 1960 s was the first major donation of art to the University. Since that time McGill has acquired three other important collections of art. A gift of $\$ 10,000$ from the Charles E. Merrill Trust in 1973 to purchase art enabled McGill to buy thirty-eight works, mostly by Quebec artists. The Montreal Star collection of paintings and sculpture was donated to McGill in 1981 after the newspaper was closed, and a collection of ten tapestries was given to the University in the 1980s by Regina Slatkin (BA '29).

Many other individual works of art have been donated by friends and graduates through the years and the McGill collection now includes more than eleven hundred items: portraits, paintings and sketches, prints, sculpture, stained glass and tapestries. It will be through the generous spirit of the University's friends that the collection will continue to grow in the future.

The catalogue that follows includes all the paintings donated by Sidney Dawes to McGill University. 


\section{Notes}

1. In 1962 McGill owned slightly more than one hundred portraits, the sculpture known by students as "The Three Bares," the statue of Queen Victoria and approximately seventyfive paintings, prints and reproductions.

2. McGill University Archives (MUA), RG41, C12, Minutes of the University Museums Committee, 28 November 1962. Dawes referred to the proposed gallery by different names: McGill Museum of Art, History of Art Collection, McGill Art History Museum, McGill Art Gallery.

3. MUA, RG1, C11, Sidney Dawes memorandum, 22 December 1962.

4. I. M. Dobell believes that Dawes and Powell together "dreamed up" the idea of an art gallery at McGill at their club, the Mount Royal Club. (interview I. M. Dobell, 12 December 1991).

5. MUA, RG1, C11, F. R. Scott to R. E. Powell, 20 July 1962.

6. MUA, RG1, C11, R. E. Powell to Arnold Wainwright, 5 December 1962.

7. MUA, RG1, Cil, R. E. Powell Memorandum, 4 May 1962.

8. Minutes of the Royal Institution for the Advancement of Learning Governors of McGill University and the Royal Victoria College, 15 Ocrober 1962.

9. MUA, RG1, C11, R. E. Powell to A. T. Galt Durnford, 22 October 1962. R. E. Powell to A. Sidney Dawes, 26 October 1962. Chairman, Dawes; Members: Profs. Frank Scott and Hare, Greville Smith, R. E. Powell, J. D. Johnston and Alice Turnham [Johannsen]; Possibilities for later consideration: Duncan Hodgson, Galt Durnford; To be contacted by Dawes: Walter Stewart through Mrs. Stewart, and Miss Caverhill. (Notes of telephone conversation between R. E. Powell and Sidney Dawes, 1 November 1962). Anson McKim was added (R. E. Powell memorandum, 12 November 1962). Alice Turnham [Johannsen] suggested that Prof. Dunbar be invited to join committee (Alice J. Turnham to R. E. Powell, 16 November 1962). Approved at the Board of Governors February 1963 (R. E. Powell to J. H. Holden, 13 February 1963).

10. MUA, RG41, C12, Statement by University Museums Committee, 5 December 1962.

11. MUA, RG1, C11, "Mrs. Pitfield's outstanding collection of Krieghoff" (R. E. Powell to A. Sidney Dawes, 14 November 1962; "Mrs. Murray Chipman has a lot of nice pictures" (R. E. Powell memorandum, 19 November 1962; Dawes would ask all his friends to donate art for the art gallery (I. M. Dobell, interview, 27 February 1992).

12. MUA, RG1, C11, Hugh Wallis [president of the MMFA] to Rip [R. E. Powell], 5 October 1962.

13. MUA, RG1, C12, Meeting to Discuss Academic Interests Common to McCord Museum and Teaching Departments, 11 January 1965.

14. MUA, RG1, C11, A. Sidney Dawes to R. E. Powell, 7 December 1962.

15. MUA, RG1, C12. There are several letters between Dawes, Powell, Hare and the candidate.

16. MUA, RG1, C12, A. Sidney Dawes to $R$. E. Powell, 5 March 1963.

17. MUA, RG41, C12, Statement by University Museums Committee, 10 December 1962.

18. MUA, RG41, C12, Minutes of the University Museums Committee, 28 November 1962.

19. MUA, RG41, C12, Minutes of the University Museums Committee, 28 November 1962.

20. MUA, RG41, C12, Minutes of the University Museums Committee, 28 November 1962.

21. MUA, RG1, C11, Alice J. Turnham [Johannsen] to R. E. Powell, 21 December 1962. Alice Johannsen Turnham was know throughout most of her professional life at McGill as Johannsen and is referred to as such 
in this paper.

22. MUA, RG41, C12, Alice J. Turnham [Johannsen] to Rocke Robertson, February 1963.

23. MUA, RG41, C12, Meeting to Discuss Academic Interests Common to McCord Museum and Teaching Departments, 11 January 1965.

24. McCord Museum, Registrar's files, W.O. Judkins to F. Kenneth Hare, 31 January, 1963.

25. MUA, RG41, C12, Minutes of the University Museums Committee, 5 December 1962.

26. MUA, RG2, C310, H. Rocke Robertson to the Chancellor, 10 December 1952.

27. MUA, RG2, C310, H. Rocke Robertson to the Chancellor, 28 January 1963, Robertson also suggested that a room should be named for Wainwright. A plan for a possible addition was prepared, (R. E. Powell to A. Sidney Dawes, 13 December 1962).

28. MUA, G1, C13, R. E. Powell Memorandum, 19 February 1963.

29. MUA, RG1, C13, A. Sidney Dawes to Gerald Finley, 22 February 1963.

30. MUA, RG1, C13, H. Rocke Robertson to R. E. Powell, 27 February 1963.

31. MUA, RG1, C13, R. E. Powell to $H$. Rocke Robertson, 27 March 1963.

32. Visual Arts Committee files (VAC), J. H. Holton to A. Sidney Dawes, 14 March 1963.

33. MUA, RG41, C12, Minutes of the University Museums Committee, 25 March 1963.

34. VAC, A. Sidney Dawes to J. H. Holton, 11 March 1963.

35. VAC, A. Sidney Dawes to J. H. Holton, 4 April 1963.

36. MUA, RG1, C12, A. Sidney Dawes to R. E. Powell, 10 June 1963.

37. MUA, RG2, C310, Alice J. Turnham [Johannsen], 13 June 1963.
38. MUA, RGl, C13, R. E. Powell to $\mathrm{H}$. Rocke Robertson, 4 June 1963.

39. MUA, RG2, C310, S. H. Schecter to H. Rocke Robertson, 24 April 1963.

40. MUA, RG2, C310, W. O. Judkins to H. Rocke Robertson, undated [27 June 1963].

41. MUA, RG2, C310, W. O. Judkins to H. Rocke Robertson, undated [27 June 1963].

42. MUA, RG2, C310, R. E. Powell to $\mathbf{H}$. Rocke Robertson, 14 November 1963.

43. MUA, RG2, C310, Stanley [S. B. Frost] to H. Rocke Robertson, 22 November 1963.

44. MUA, RG2, C310, Senate Development Committee: Report of the Sub-Committee on the McCord Museum, 16 June 1964.

45. MUA, RG2, C310, R. E. Powell to $H$. Rocke Robertson, 7 October 1964.

46. MUA, RG2, C310, R. E. Powell to A. Sidney Dawes, 12 November 1964.

47. Dawes presented invoices with his donations. Unfortunately most were returned to him.

48. One painting, an Arctic scene, was found in Ottawa in the offices of the Arctic Institute which had been housed on the McGill campus from 1948 to 1975 .

49. The biographical information was supplied by John Bourne, Dawes's son-in-law, December 1991.

50. MMFA material from the Archives and Director's office, MMFA, January 1991.

51. Interviews with Walter Klinkhoff and Joan Bourne (Dawes' daughter). Also Powell to Dawes, 29 November 1962, "Grenville Smith is also 'fed up' with the Museum." 


\section{The Sidney Dawes \\ Collection at McGill University}

A Catalogue 
Sidney Dawes and the McGill Museum of Canadian Aut
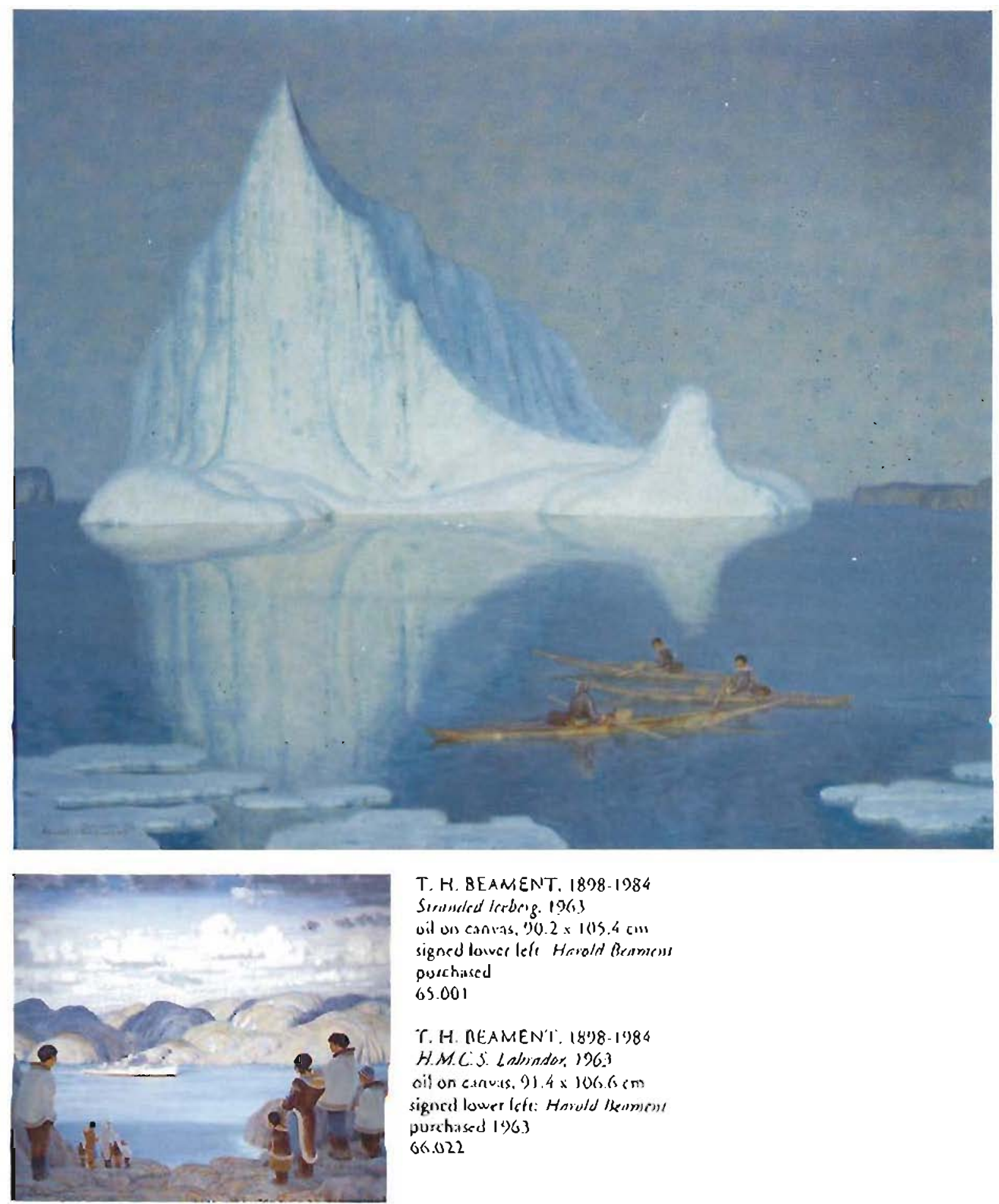

T. H. BEANENT. $1898-1984$

Sirusded lerberg. 196,

uid us canvas. 90.2 $21015.4 \mathrm{~cm}$

signed lowee lefe Horold Besmens

puschinsed

65.001

T. H. DEAMEN'. 18')8-1984

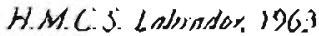

ail on cinvils. $91.4 \times 106.6 \mathrm{~cm}$

signal lower lofe: Howld lxamenst

purchased 12)63

66.022 
Sidney Dawes and the McGill Museum of Canadian Art

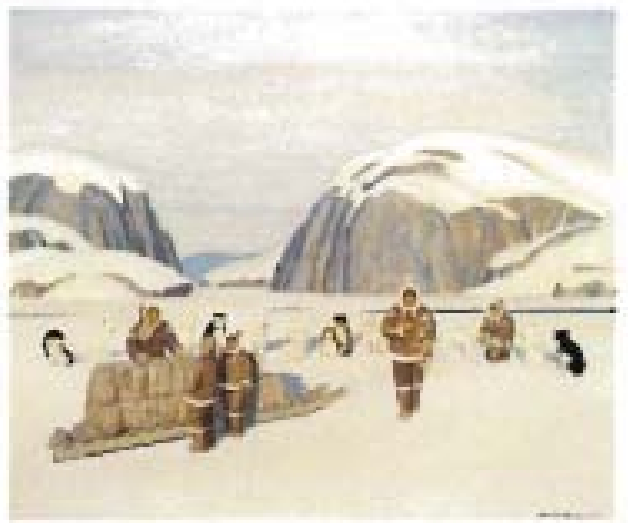

At left:

T. H. BEAMENT, $3898-1984$ Winter Irand

Boffis biond, 1963

sil on canvas

$90.2 \times 105.4 \mathrm{co}$

signed lower righte

Horald Besment

purchased

65.002
Below:

T. H. BEAMFNT, 1858-1984

Sowethong in Siglw, 1949

oil an anvas

$91.4 \times 106.6 \mathrm{~cm}$

signed lonver right:

Hasmbal Bomesiz

perclased $1 \%$ G

66,021

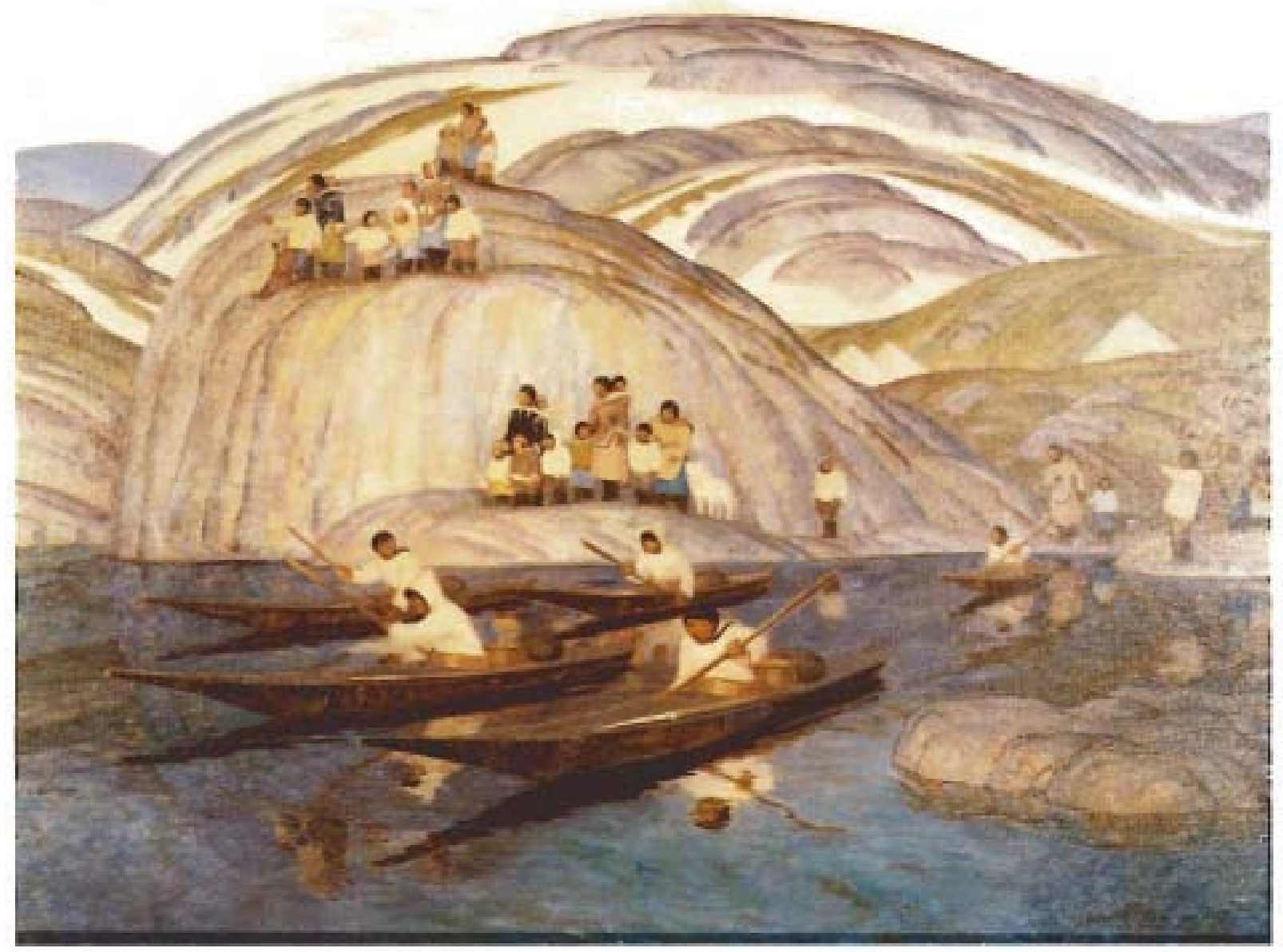




\section{Sidney Danes and the McGill Museum of Canadian Art}

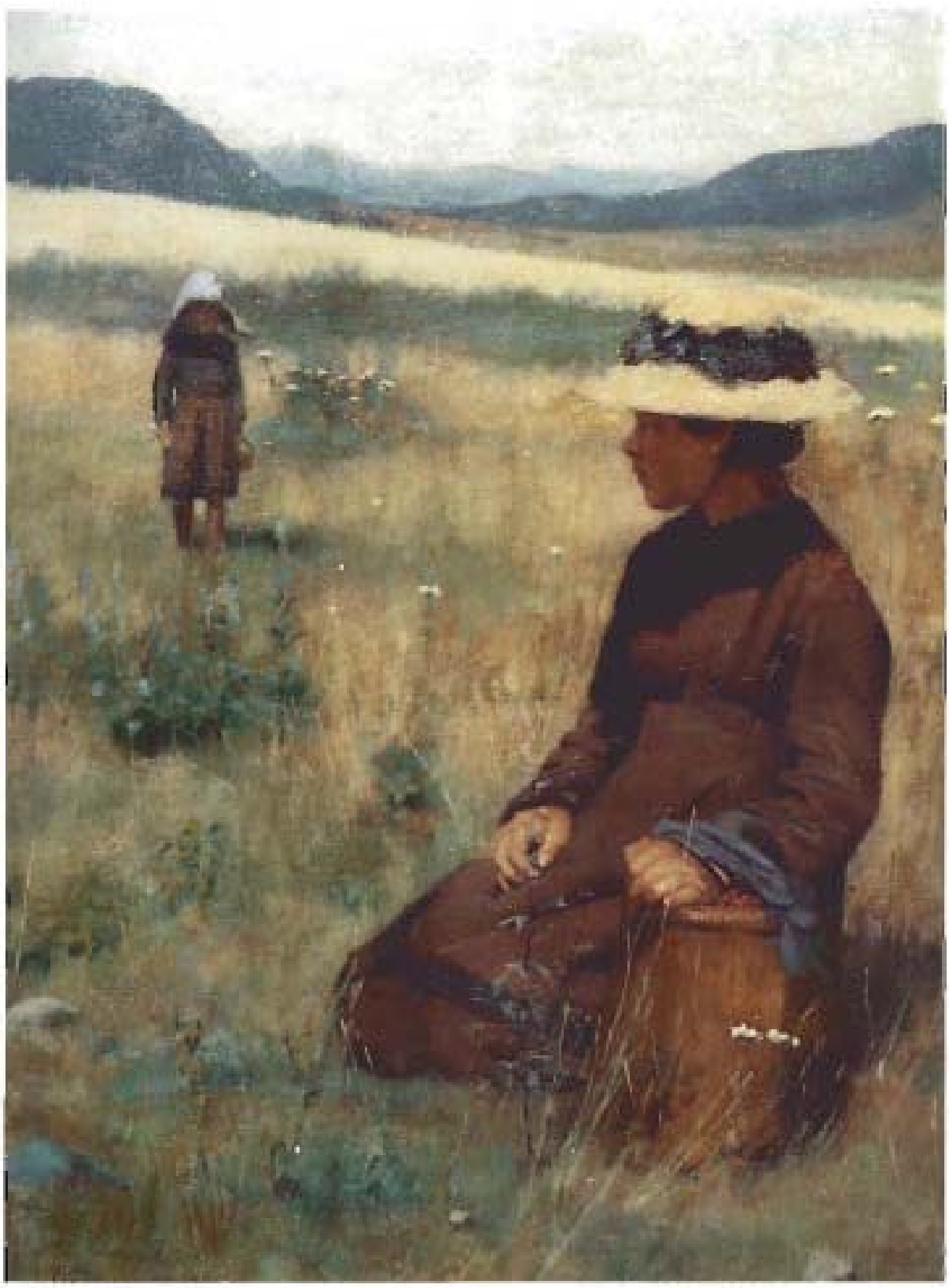

WILLIAM BRYMNER

1855-1929

Garherang Wrida

Stranubernies 1885

oil on canvas

$54.2 \times 39.7 \mathrm{crn}$

signed lower left:

Wor brgmart is8s

ourchased

Dommion Galicry

Monteal 1963

6.3.0.15 
Sidney Dawes and the McGill Museum of Canadian Art

At right: WI11.IAM BRYMNE.R. 1855-1925

Autumm River, ca 1915

sil on pancl, $24.1 \times 3.3 .1 \mathrm{~cm}$

signed lower right: Wm. Brymuer

purchased Walter Klinkhoff (jallery 1964

66.016

Beluw: FRANKI.IN CARMICHAF1., 1890-1945

W'hicefish Hills. 1933

vil on canvas. $76.2 \times 91.4 \mathrm{~cm}$

purchased Blait Jaing. Toronto 1964

65.017
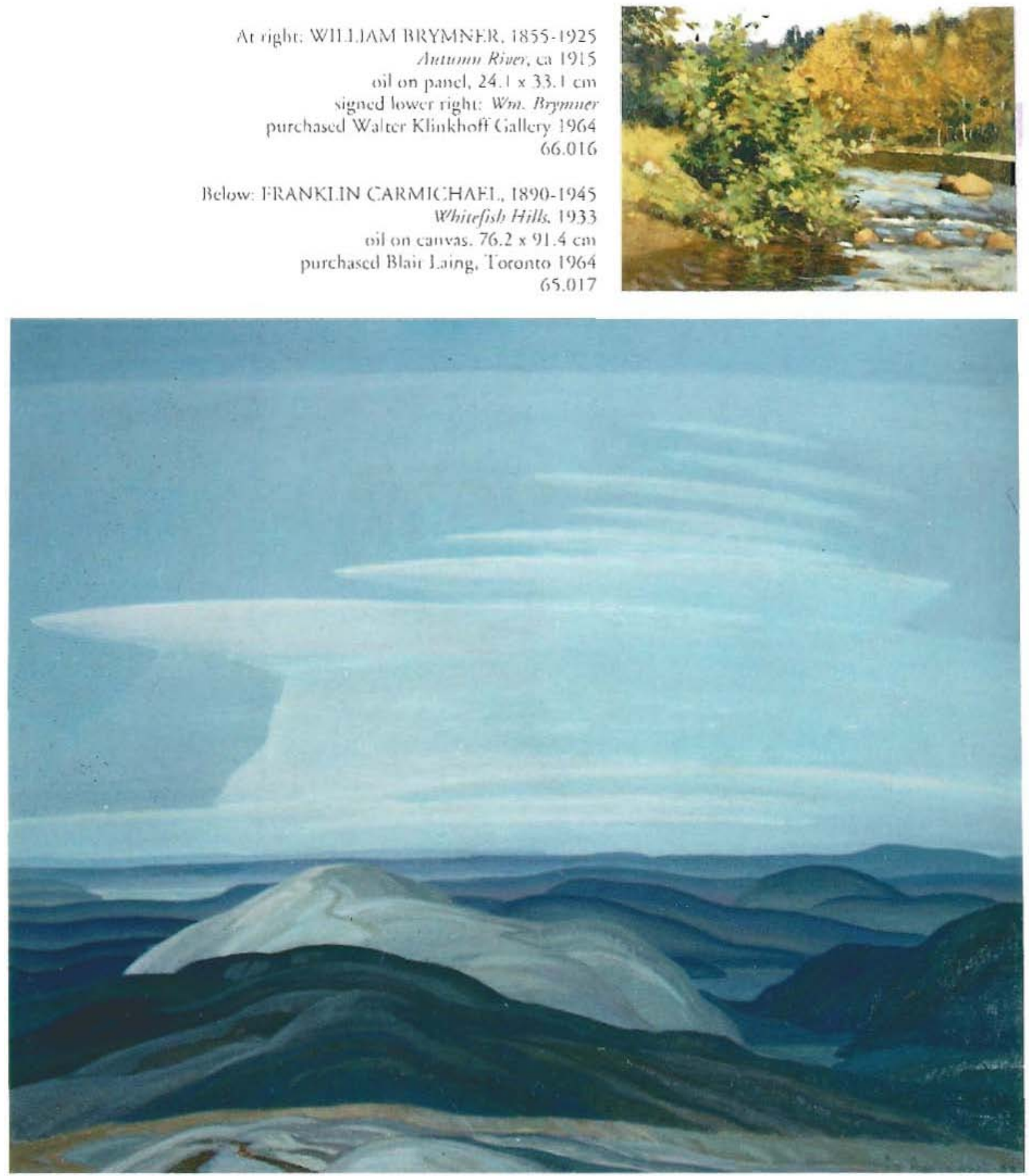


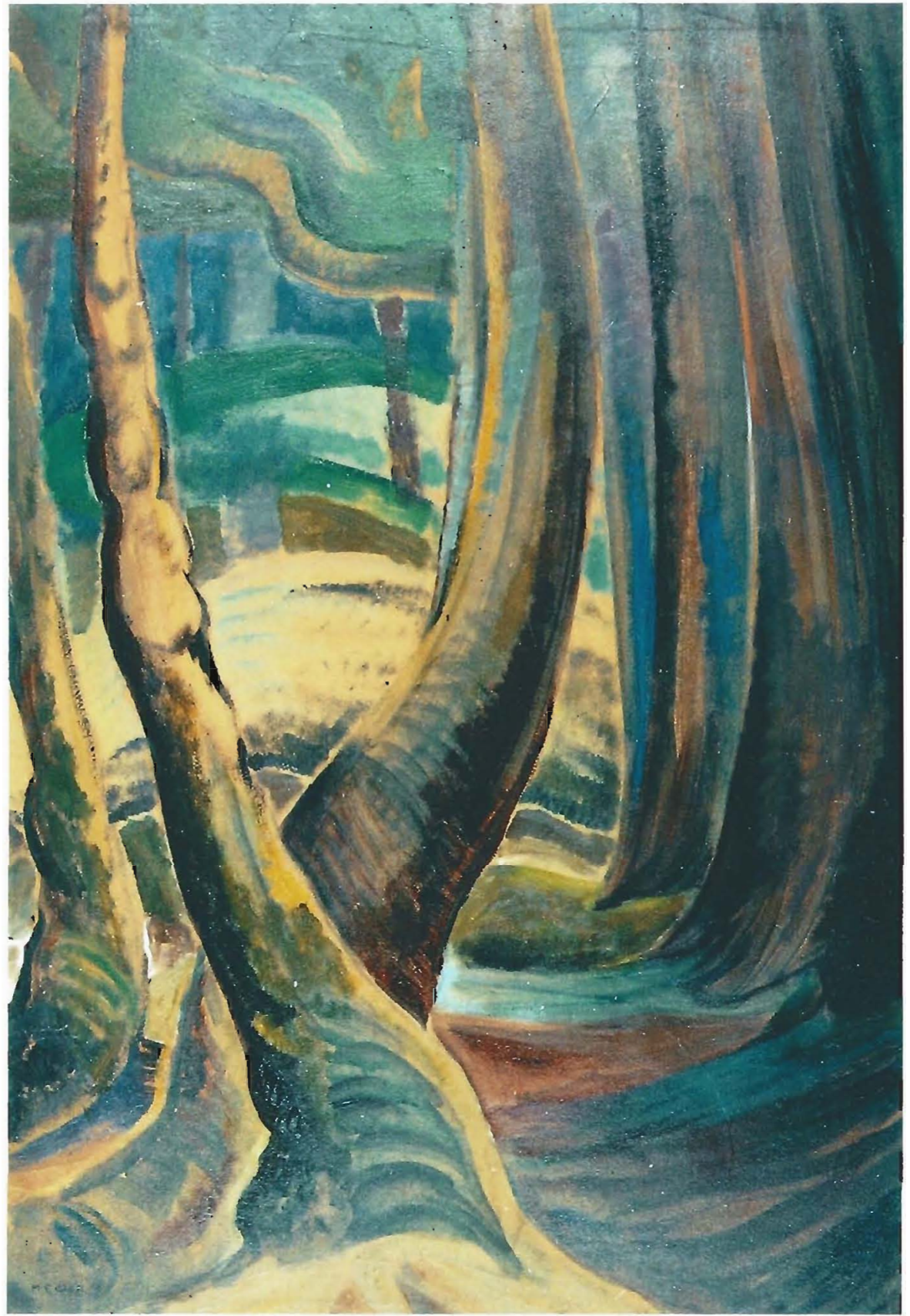

Above:

EMILY CARR, 1871-1945

B.C. Forest, Ca 1934

oil on paper, $91.4 \times 61.0 \mathrm{~cm}$ signed lower lef: $M E C A R R$ 66.004
Bchow:

FMIIYY C.ARR. 1871-1945

Indian Sibnot, Lyteon. B.C.

1910

watcreolour

$38.5 \times 54.6 \mathrm{~cm}$

signed and dared lower righr: M. FiMULY C CAR? purchased Akex Fraser Vancouver 1964 64.002

in 192), Fmily (are wrote in an arricle encicled "Modcru and Indian Arr of rhe Wist Coast" in a Supplement to the Mc(iill Nezus (June 1929) in which she described her arios ro Indian territory: "l would work hiard all winrer ro be able ro afford a rrip ro the villages in the summer, for rilus off the beater irack coss molley First i skerched in a desulrory way jusc for the joy of ir, burby and by I began ro realize rhar these rhings were passing and I srarred in earnest to make a collecrion of painrings of the villages and rorem poles. I did nor do many portrairs of the people because I found ic hurt them so. The old people, who werc rhe incerescing ones, were superstirious; they believed that the spiric was rapped in the picture and would for ever be hald there."

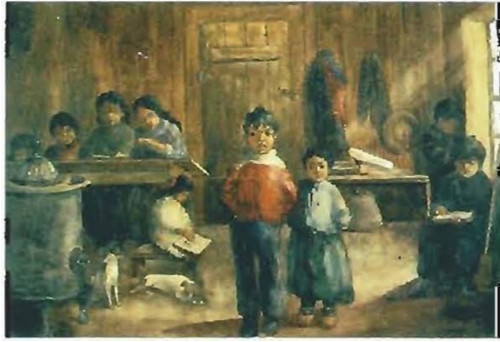

89 
Sidney Dawes and the McGill Museum of Canadian Art

A.J. (ASSON, 1898-1992 On the North C.hannel litule Current, ca 1959

oil on canvas

$61.0 \times 76.2 \mathrm{~cm}$

signed lower righe:

A.). C.ASSON

6.3 .008
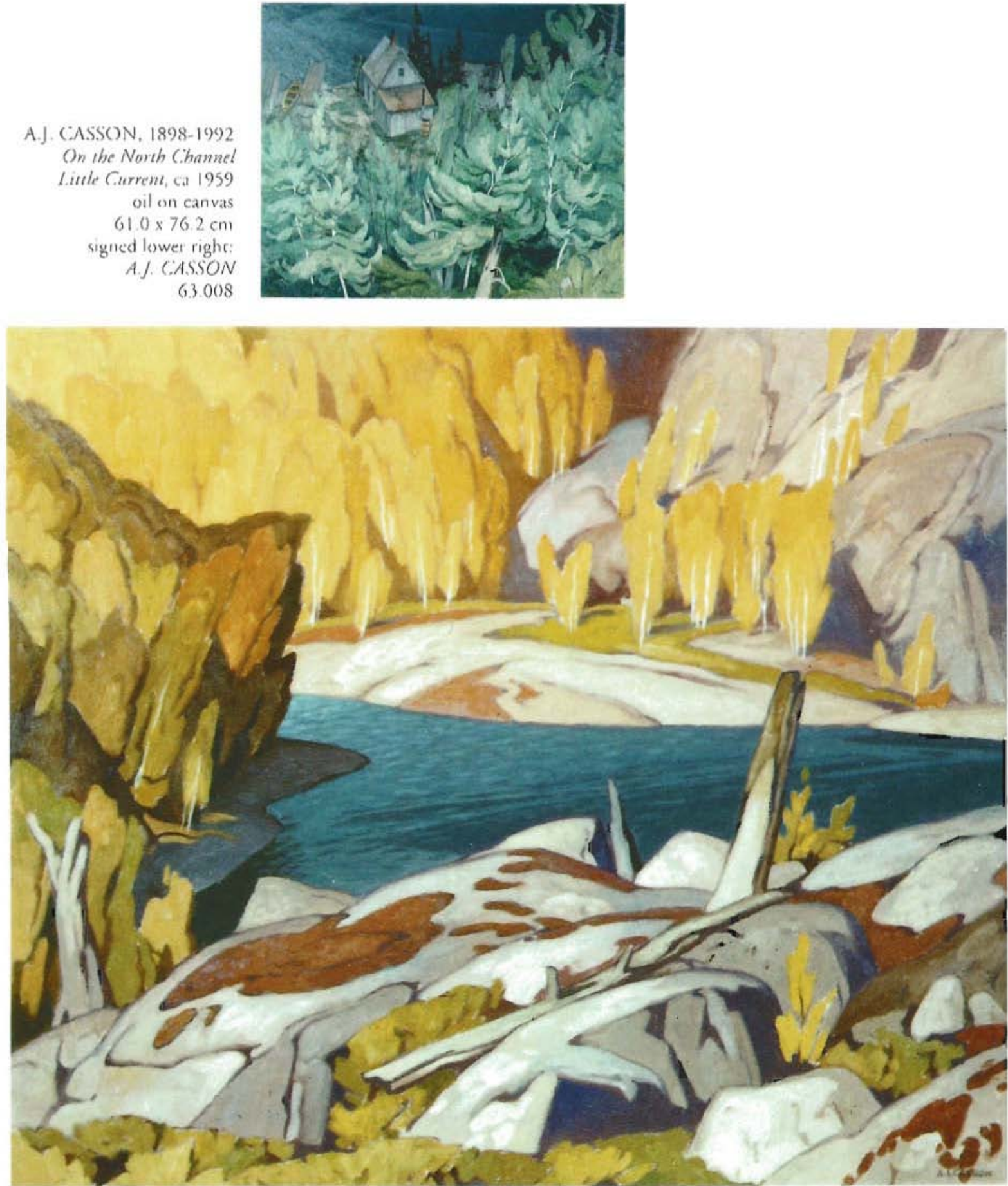

A.I. CASSON, 1898-1992

Northern Lake, ca 1960

oil on panel, $50.8 \times 61.0 \mathrm{~cm}$

signed lower right: $A$. .J. CASSON

purchased Walter Klinkhoff Gallery

1964

66.015 


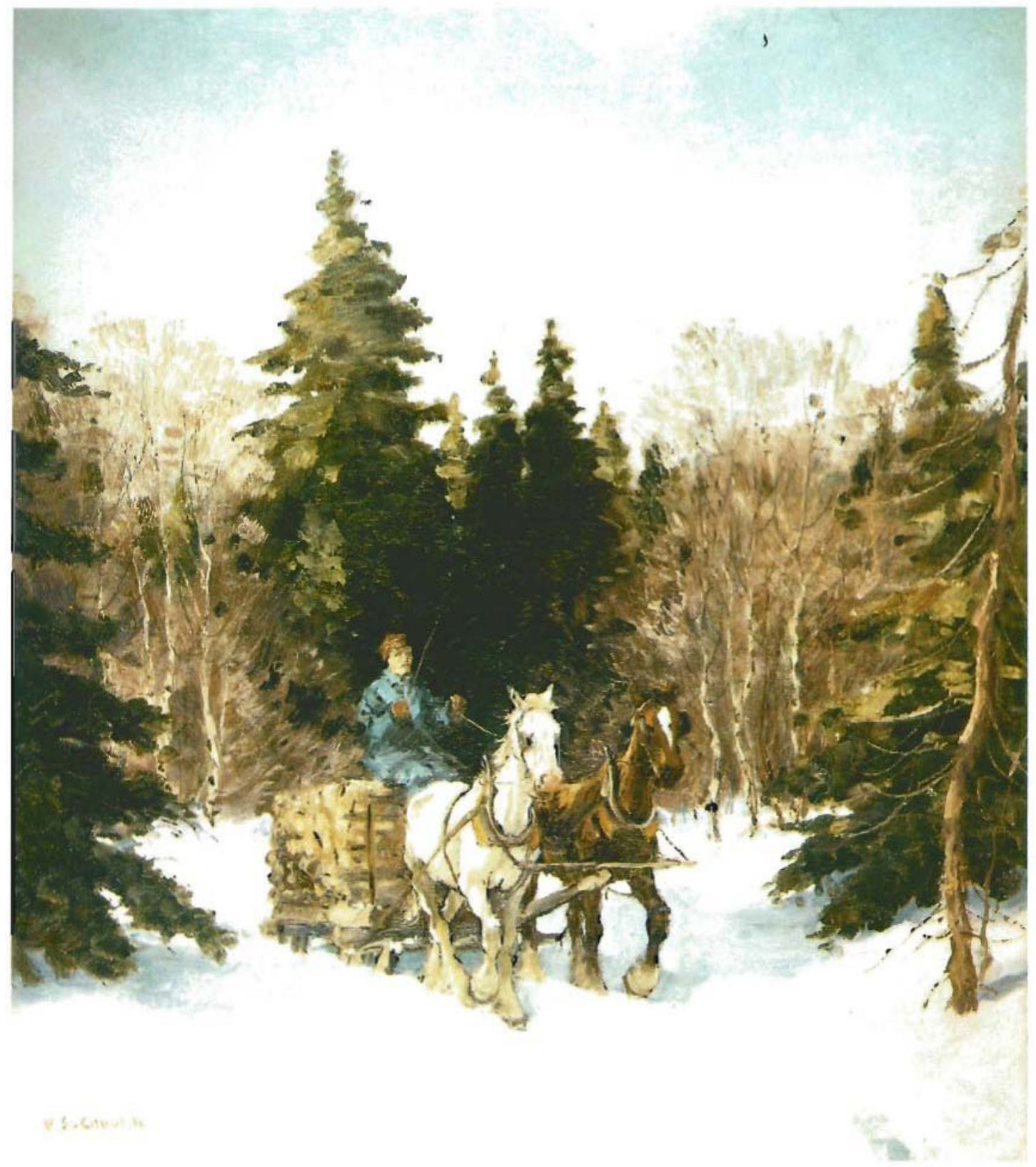

F.S. CUBURN, $1871-1960$

Logging Team, 1928

oil on canvas, $64.7 \times 57.1 \mathrm{~cm}$

signed lower right: FS. COBURN 28

purchased from

Kenneth T. Dawes 1963

64.003 
Sidney Dawes and the McGill Museum of Canadian Art

ALAN LIDSON $1846-1888$

thiest with brook in Autumm, cal 1874

wasercolour

$58.4 \times 43.2 \mathrm{~cm}$

$6(3.0) 18$
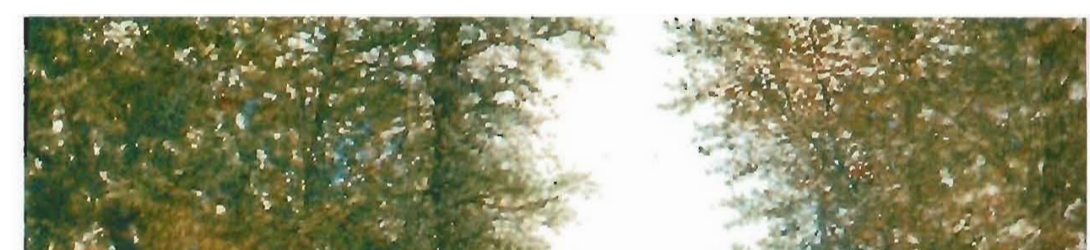

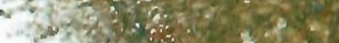

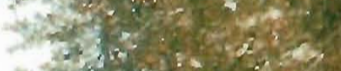
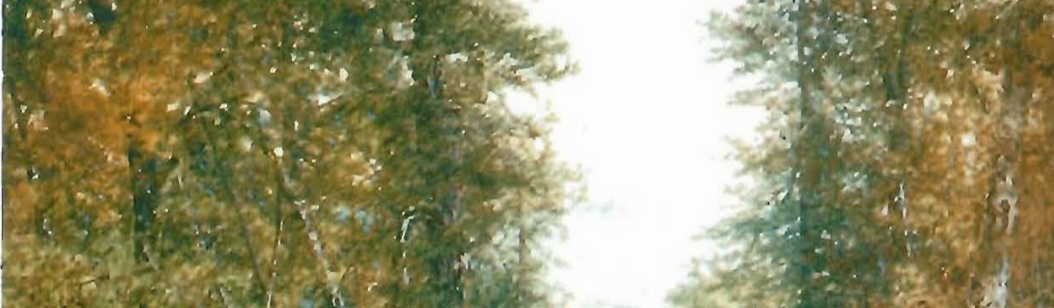

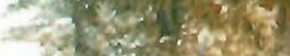
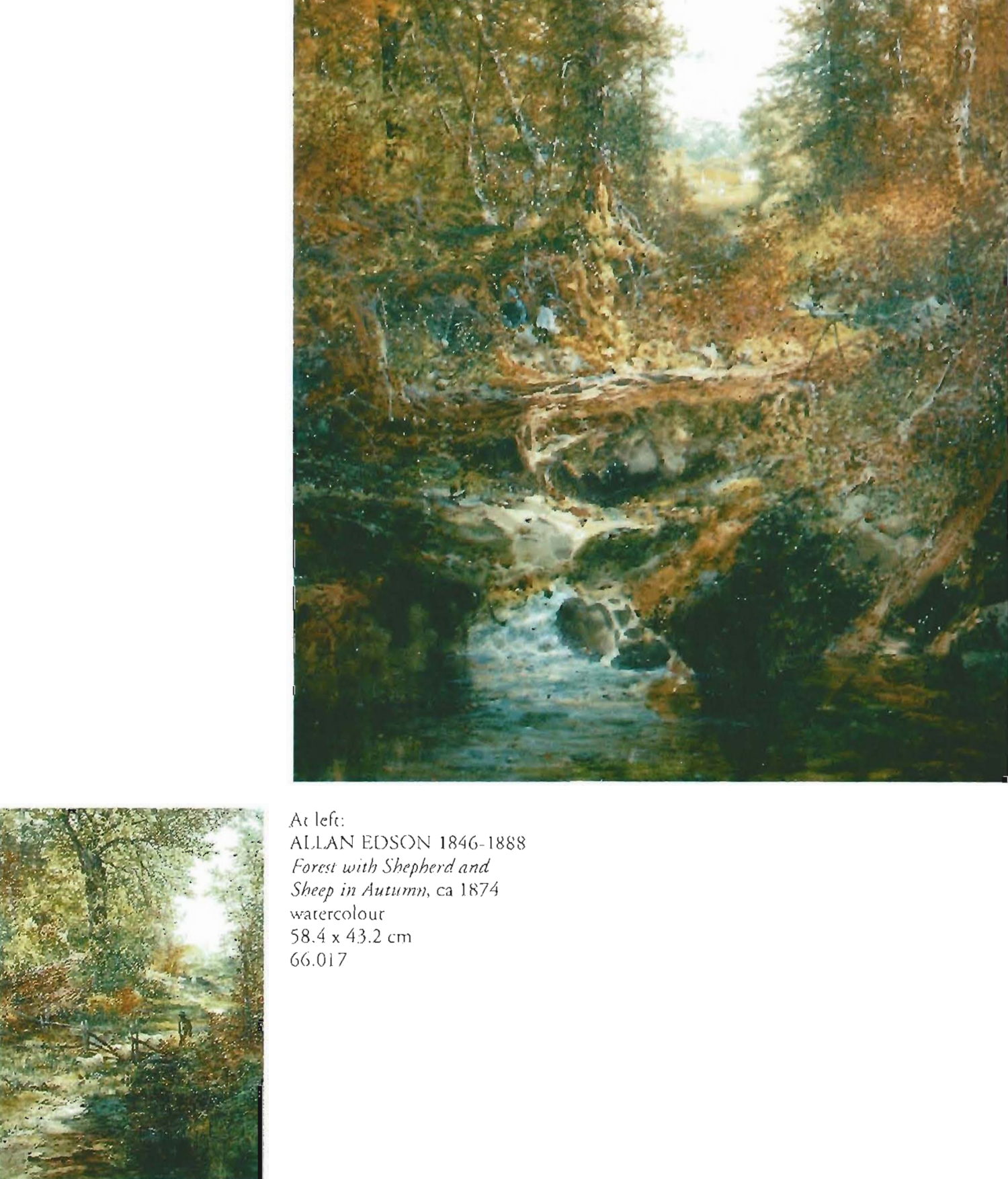

Acleft:

ALLAN EDSON 1846-1888

Forest with Shepherd and

Sheep in Autumn, ca 1874

warercolour

$58.4 \times 43.2 \mathrm{~cm}$

66.017 
Sidney Dawes and the McGill Museum of Canadian Art

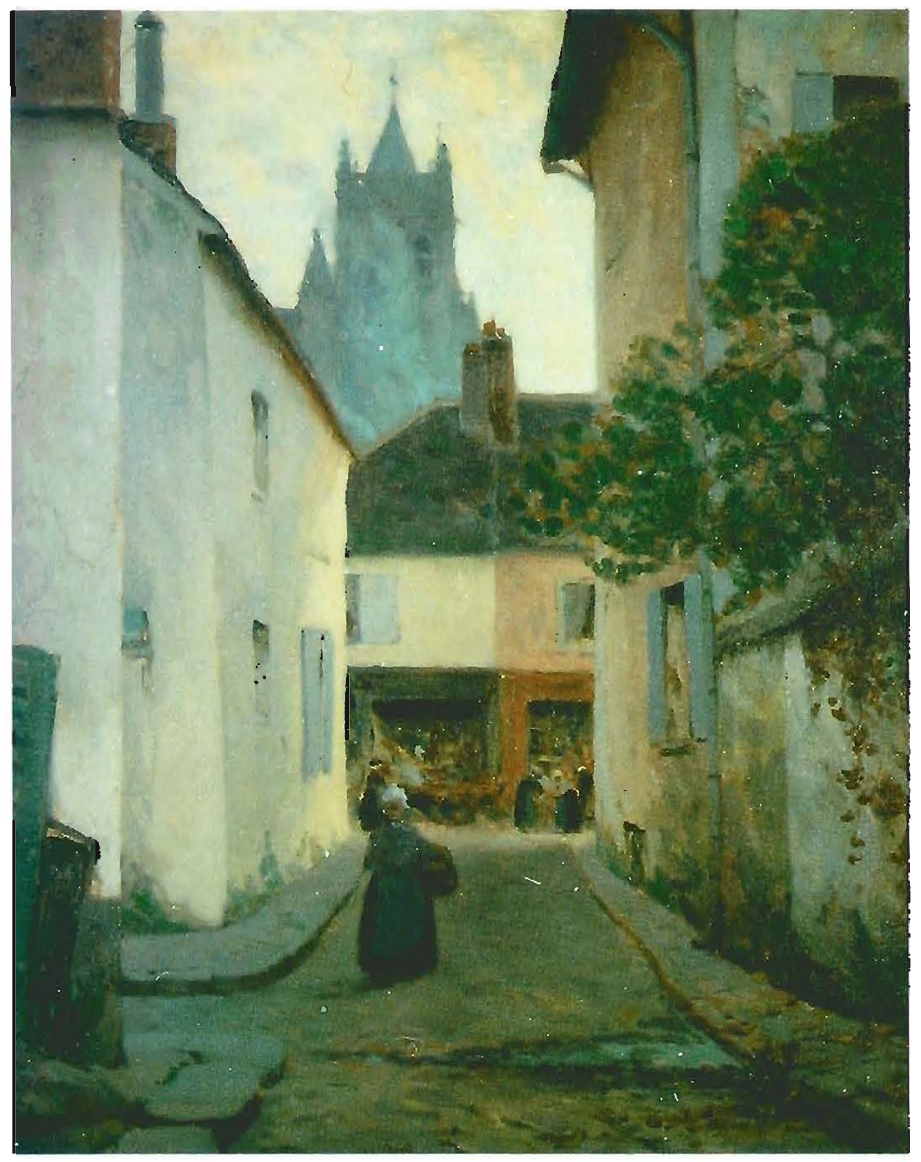

CLARENCH (AMGNON

1881-1942

Street in Disum, 1908

oil on canvas

$78.8 \times 6.3 .5 \mathrm{~cm}$

purchased from

Kennedi 1'. Dawes

196.3

60.023

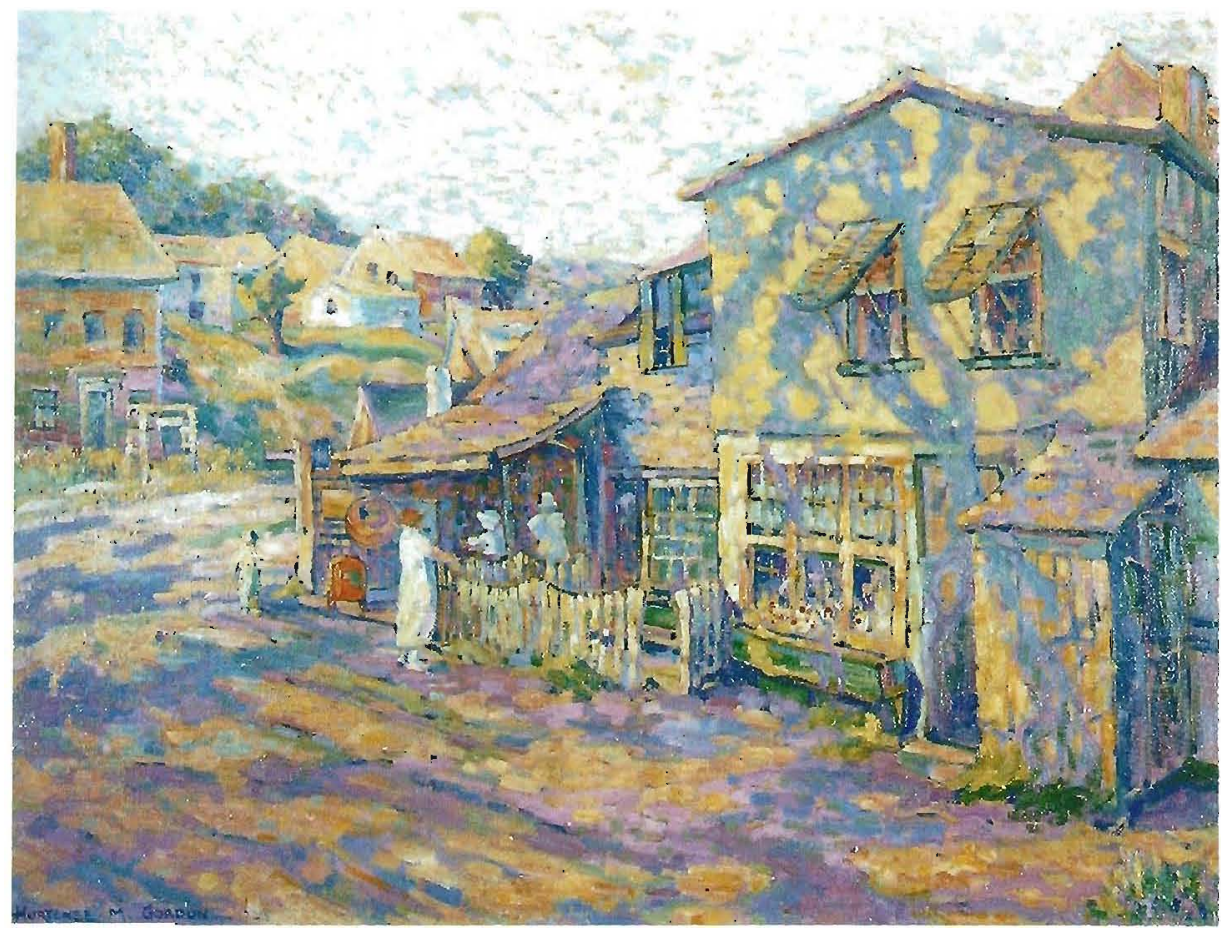

HCORIYNSL GORDON $1889-1961$

Coustry Stome, 1925

ail on carrvals

61.0 $\times 81.3 \mathrm{~cm}$

signed lower left:

HORTLINSEM. (IORD)ON purclased 1965

66.024 


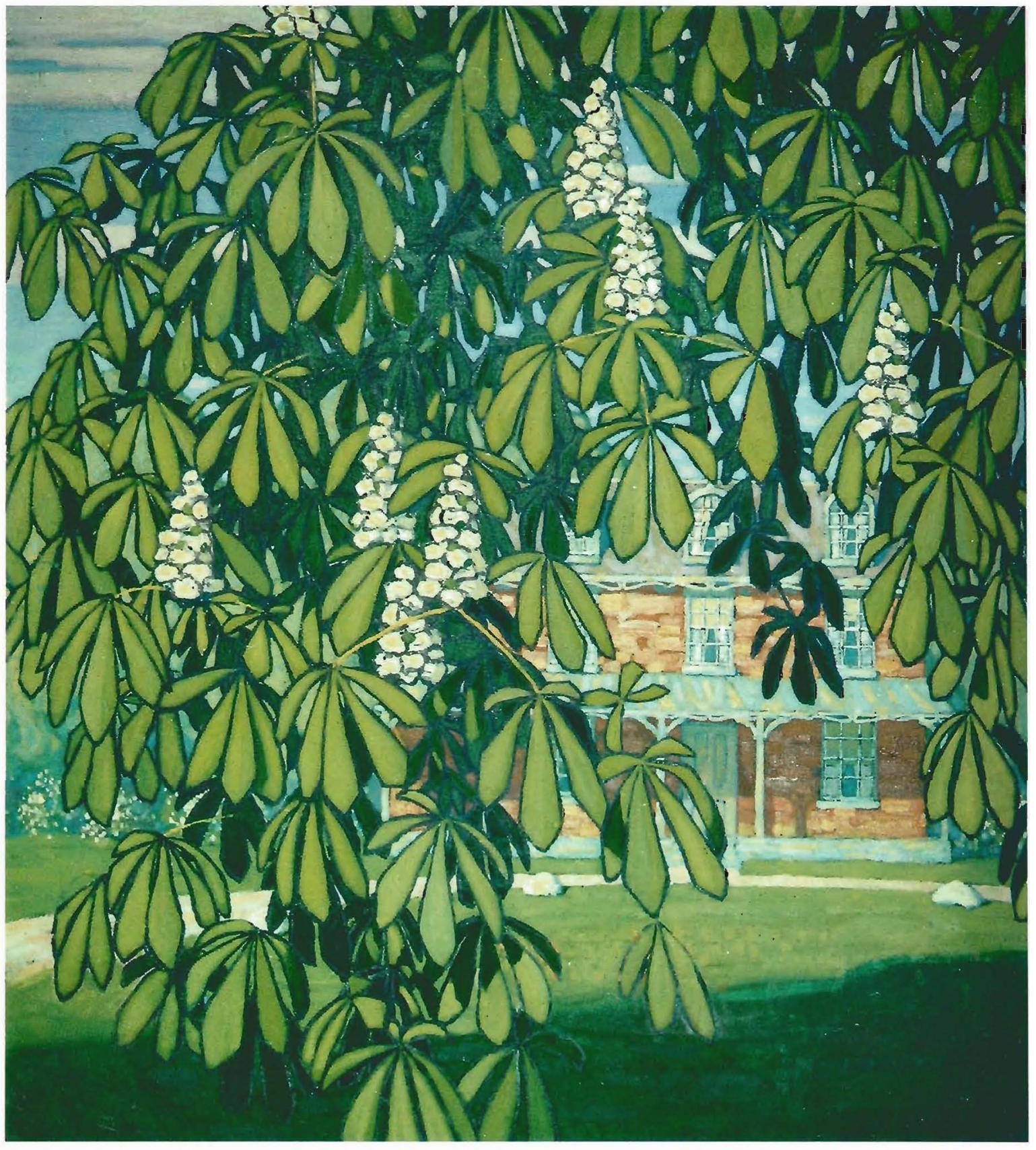

Ar righu (and on cover) LAWREN HARRIS $1885-1970$

Red Sleigh, Howse Winter, 1919 oil on canvals, $116.8 \times 1.32 .1 \mathrm{~cm}$ signed lower left I.AWREN/HARR/S/19/9 purchased Blair Laing, Torences 1962 60.001

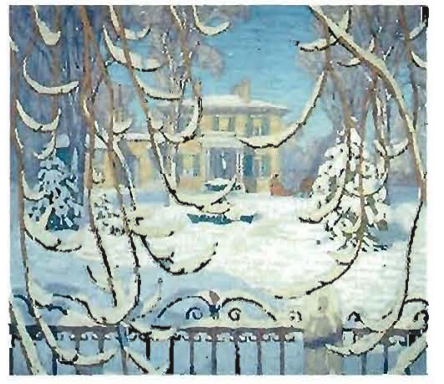

LAWREN HARRIS, $1885-1970$

Chestnut Tret, House, Barrie, 1916-1917 oil on canvas, $113 \times 101.6 \mathrm{~cm}$ signed lower righe: IAWREN/HARRIS purchased Donsinion Gallery, Moncreal 1964 66.008

This painting was cxhilited in the lawren Harris Rerrospecrive Exhibicion ar the National Callery of Canada in 1963. 


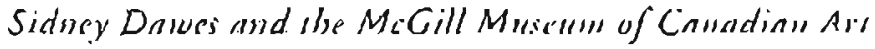

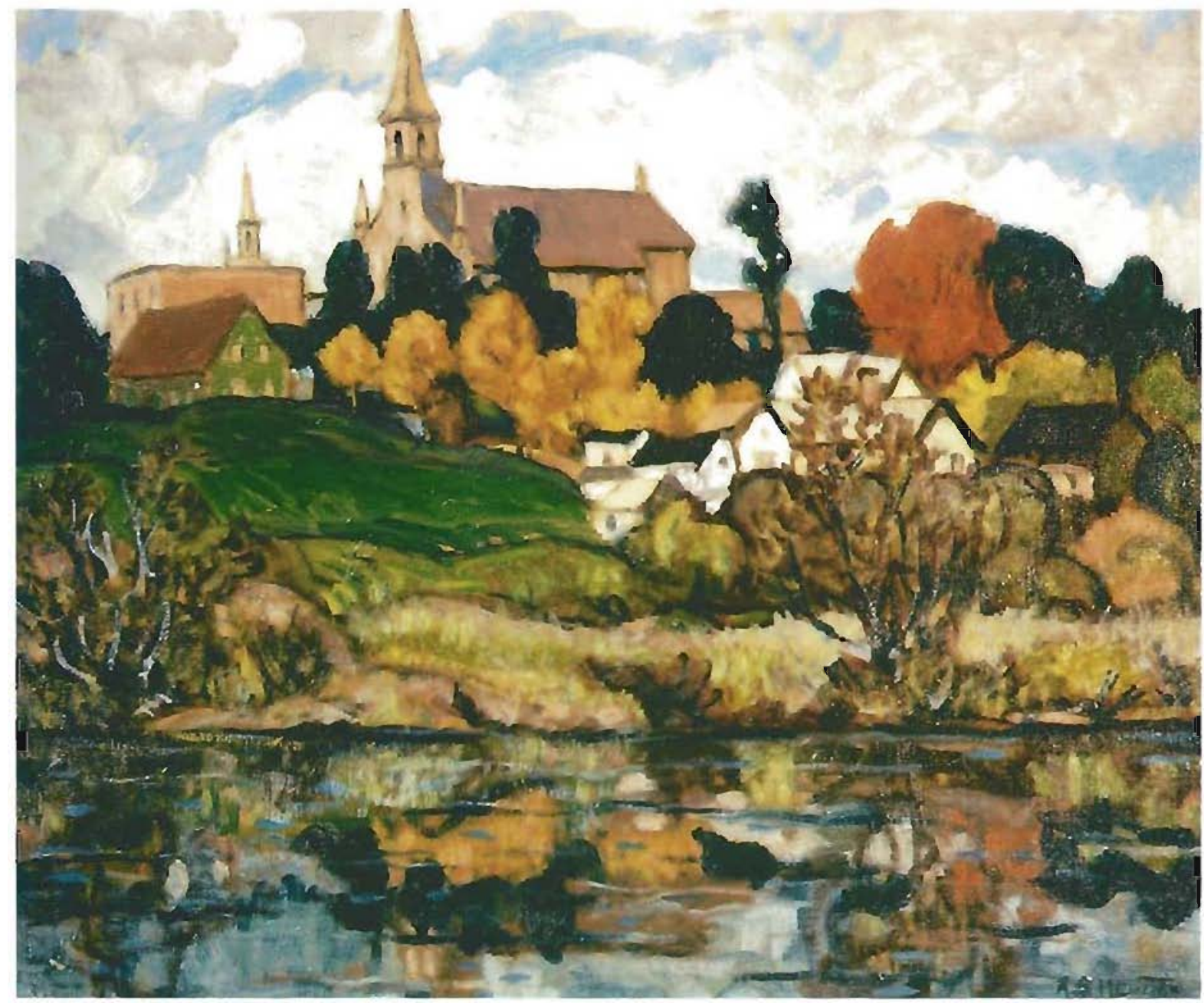

Abriv:

RANDOS.PIIHFIEION $1888-1560$

Si. Iin. Ir: Cisp! Cosoloneir conuty ca (i) 2)

ail on a anvas

$50.8 \times 69.0 \mathrm{~cm}$ signexi lowe right: RSHFWTON purchascal 1965 66,026

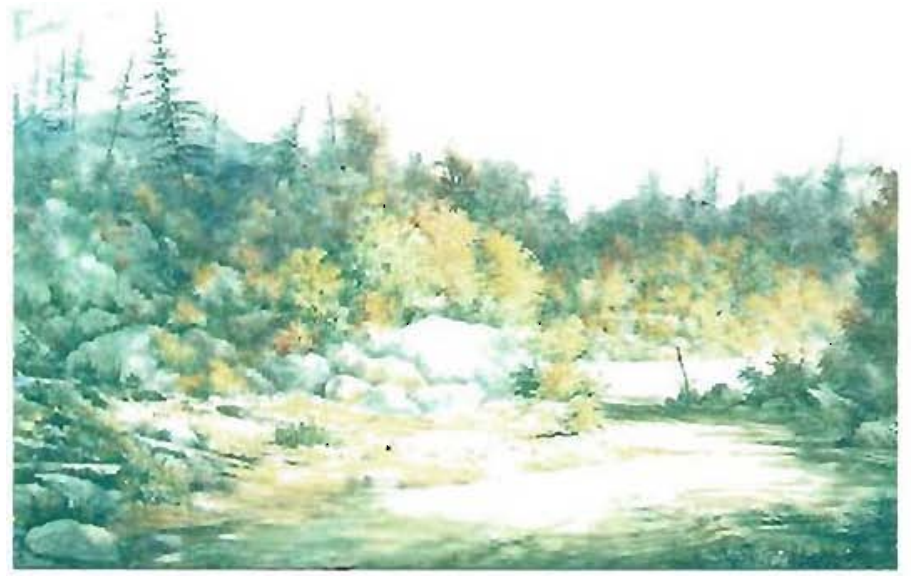

Mlefi:

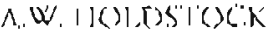
$|82(1.11)()|$

Grestabove l.npwir

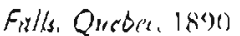
valeicolout $3 \hat{3} .6 \times 32.7 \mathrm{~cm}$ signed lower lidi: Cinek abondhl'me

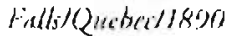
pliclijsed Dominion (iallers: Manoreal 196.5 6.3 .003 
Sidney Dawes and the MeGill Musesm of Canadian Art

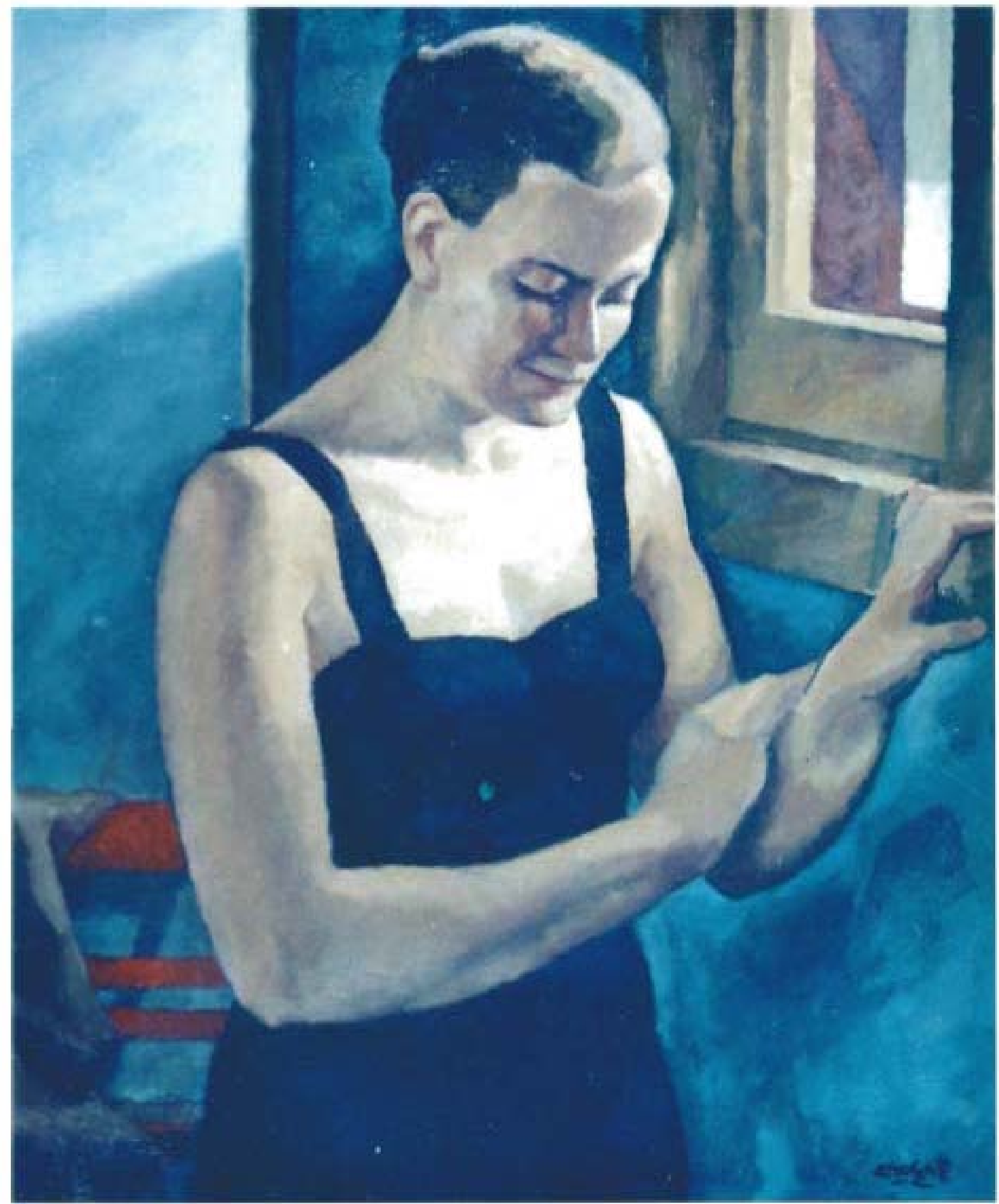

GPWN HOLTATE, $1692-197$

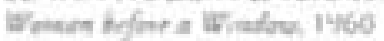

oul an can*as, $65.1 \times 34.6 \mathrm{can}$

Egetd lowen neht. E HOLGtiF

parchaed Dominiman Gallor, Mantreal 1462

63.002 


\section{Sidnry Daturi and the McGill Muirum of Canadian Art}

Neat righr:

FW. HUTCHISGN, 1871.1953 Labe of Tav Meuninier in Wisern, 1945 oil oa canvas. $768.921 \mathrm{~cm}$

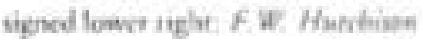

65004

tarnitir

F W. HUTCHISON, 1871-1953

Astamen Lendenepr, Farm noer St. Urbrix 1940

oil on canvis, $65.1 \times 188.9 \mathrm{~cm}$ signed lower night A.W. Matehaes 65.005
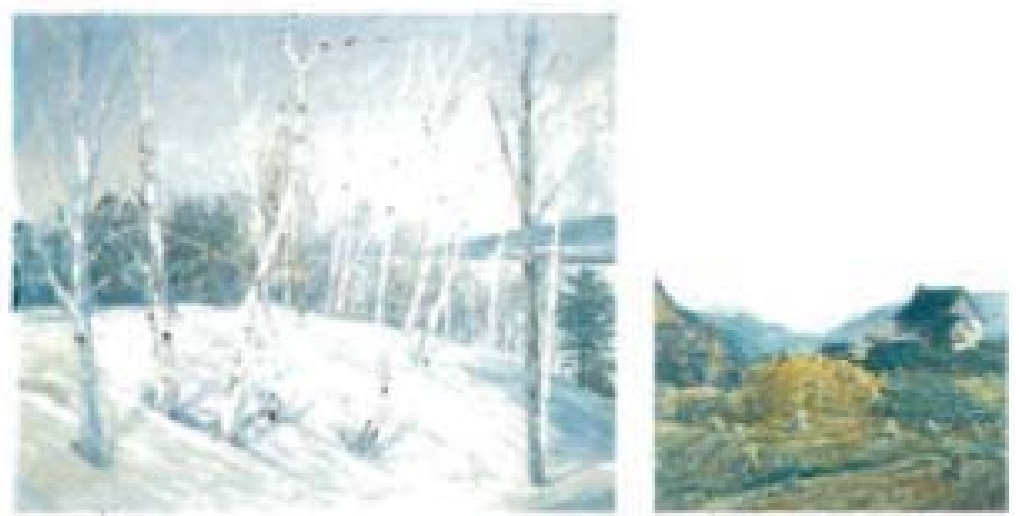

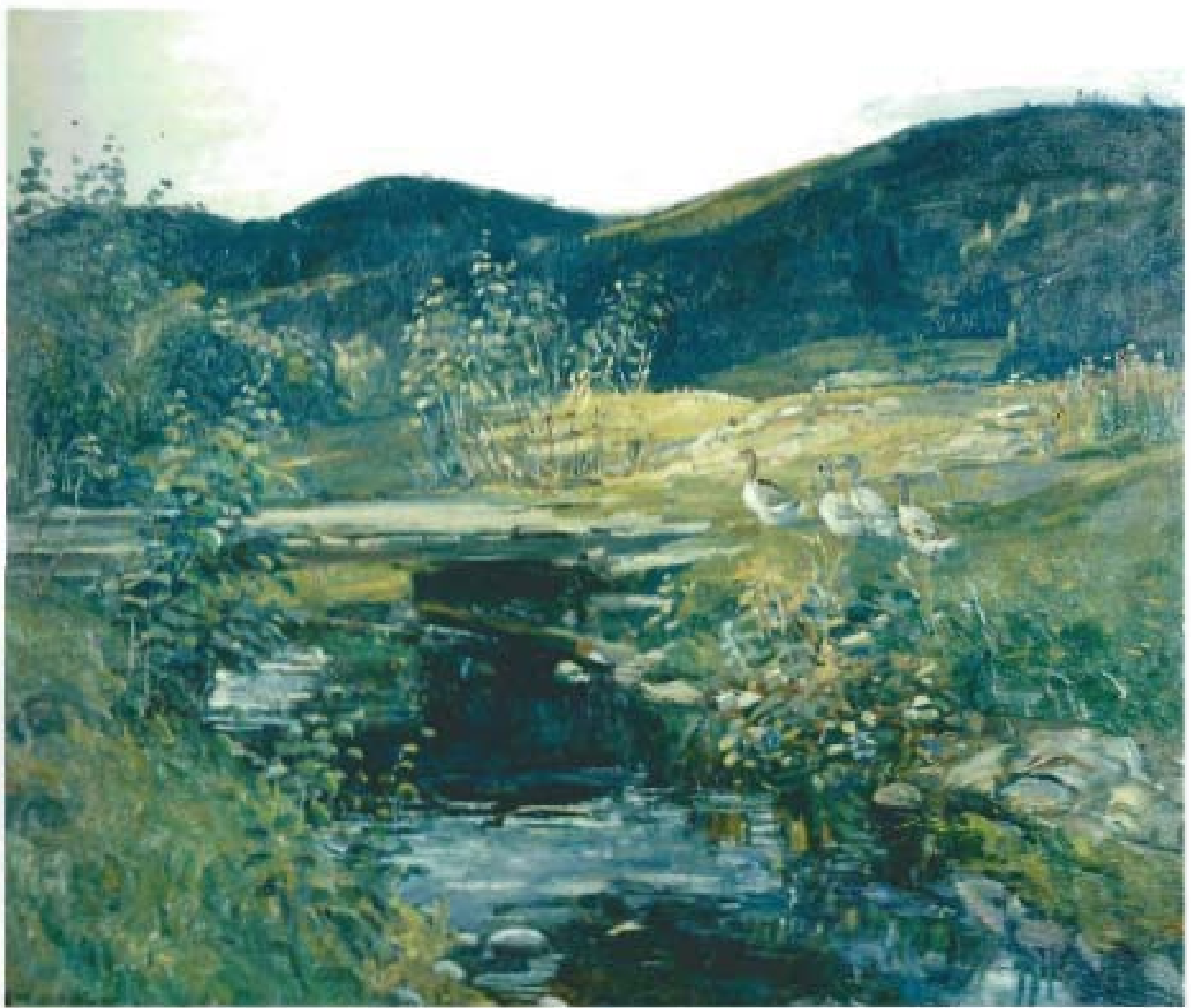

F.W HUTCHSON, I67-1953

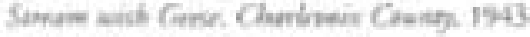

eil on amvat. $659 \times 76.2 \mathrm{~cm}$

aferd lower lefe $f$ o Haskoum

65.006 
Sidney Dawes and the McGill Museum of Canadian Art

A.Y. JACKSON, 1882-1974

Dawn in the Yutkon, 1943

oil on cinvas, $81.3 \times 101.6 \mathrm{~cm}$

signed lower left: A Y Jackson

purchised Duminion Ciallery

Montreal 1962

6(6.00)

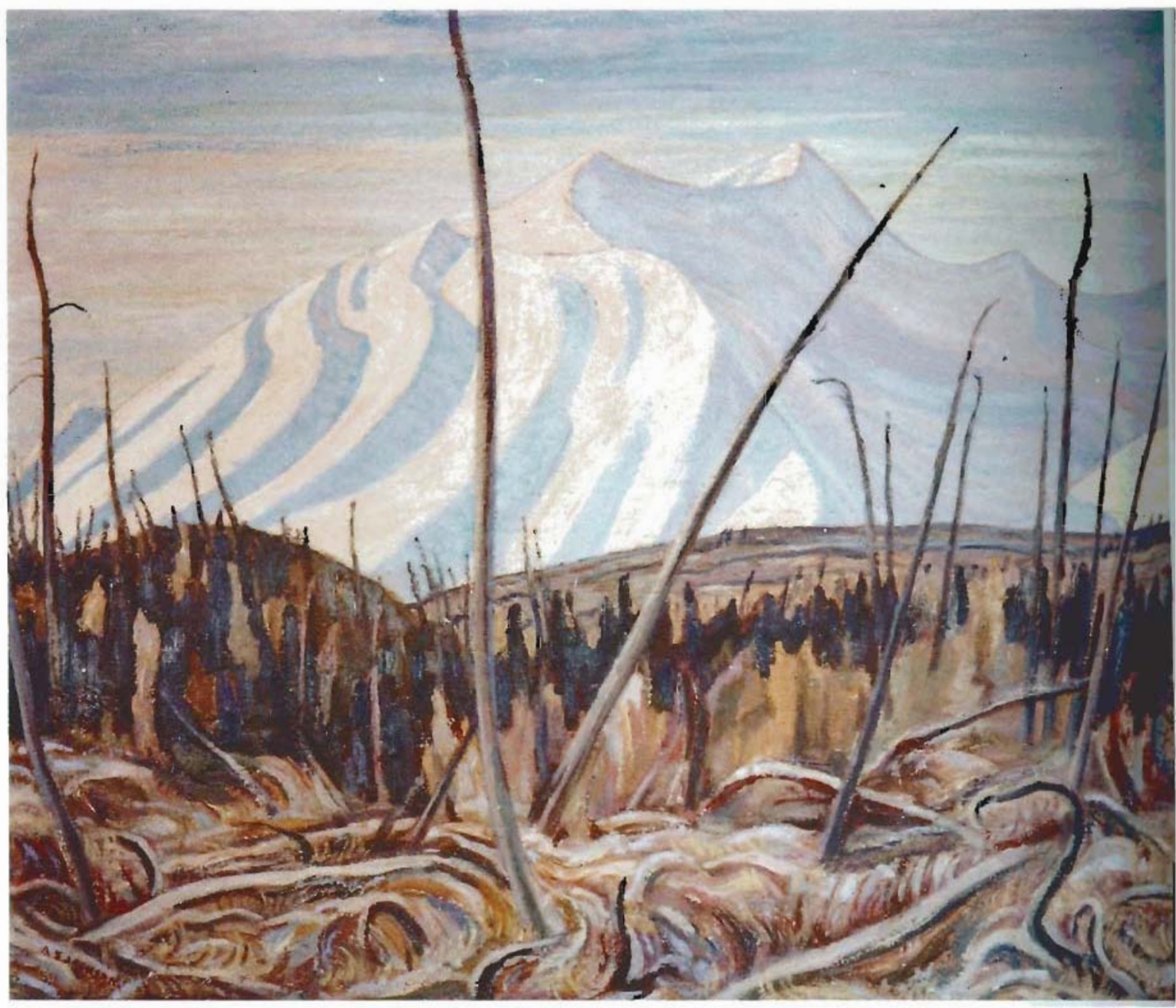

A.Y. JACKSON, 1882-1974

Great Bear Lake near

Port Radium, 1963

oil on canvas

$81.3 \times 101.6 \mathrm{~cm}$

signed lower righe:

A Y JACKSON

purcliased

Dominion Gallery

Montreal 1962

66.012

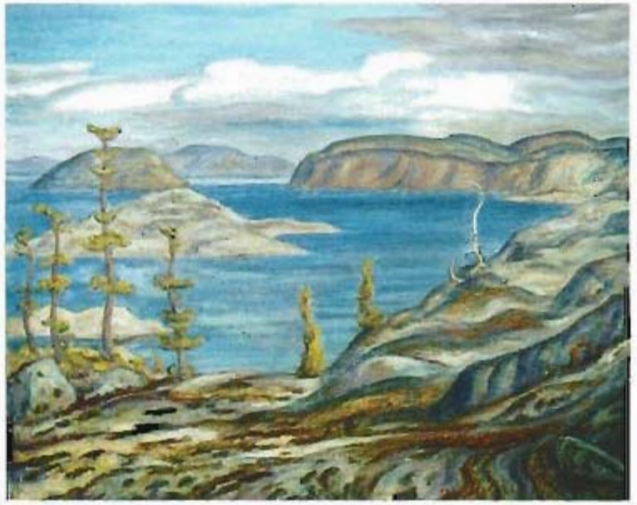


Sidney Dawes and the McGill Museum of Canadian Art

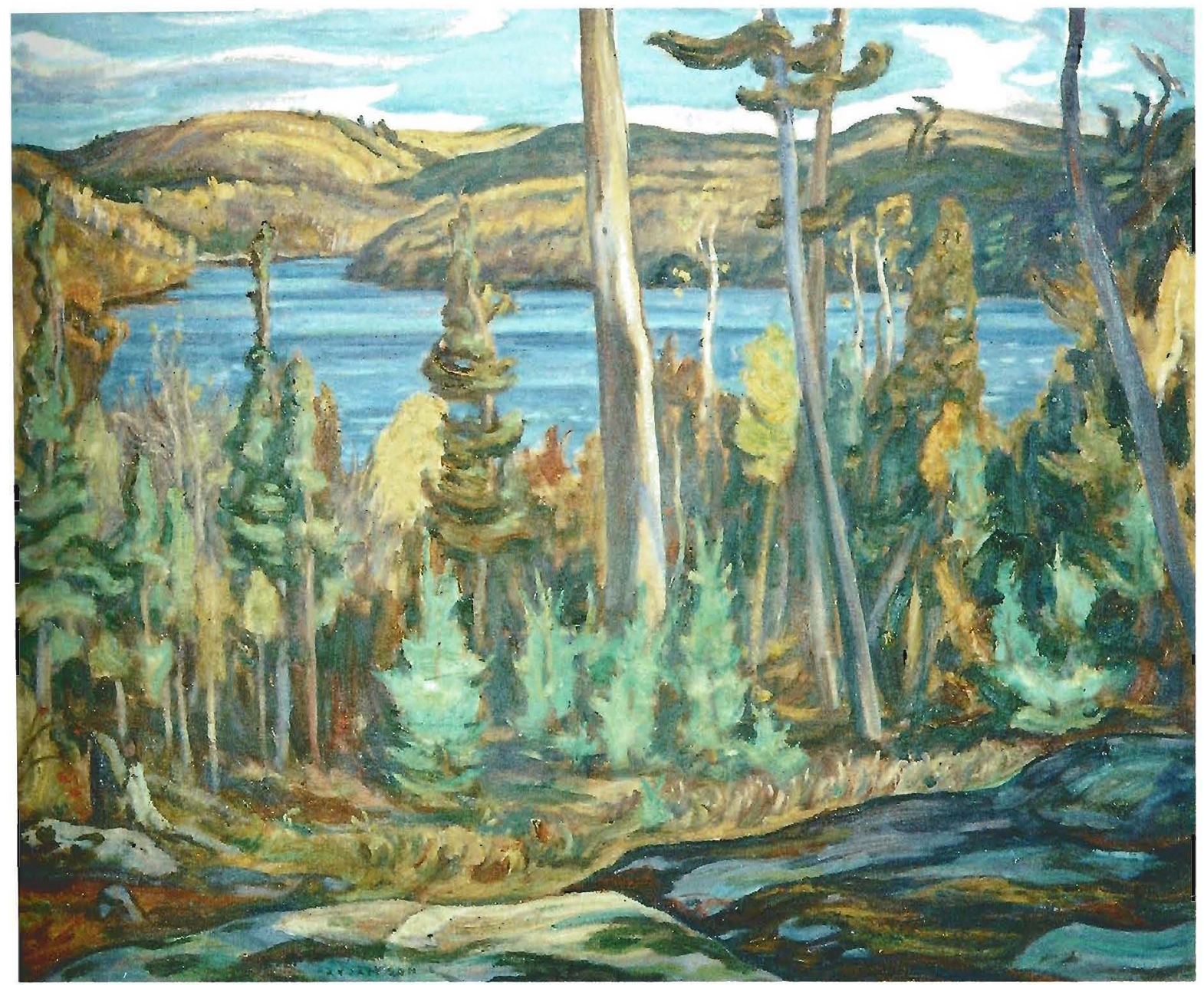

A.Y. TACKSON, 1882-1974 Autumn in Temagami, 1955 oil on canvas $81.3 \times 101.6 \mathrm{~cm}$ signed lower lefr: A Y jackson purchased 1964 66.005 lackson's niece, 1)r. Nanmi Groves wrote (to the authoi, 17 September 1990): "... onc amazing bonus is that the Tenagami 1955 canvas is painted ac the place I go to every (almost) summer, the Shining Wood Lodgc on North Maline Lake 10 miles sourh of 'lemagami village, I recognize the lake, he had the cottage 2 cloors down from mine and it was $A Y$ who rold my husband Walcon and me abour that nice place to stay, so I ruly have rhe sense of a sorc of miracle ar work - think of ic being there ac my universiry since the 1960s." 
Sidney Dawes and the McGill Miseium of Canndian Art

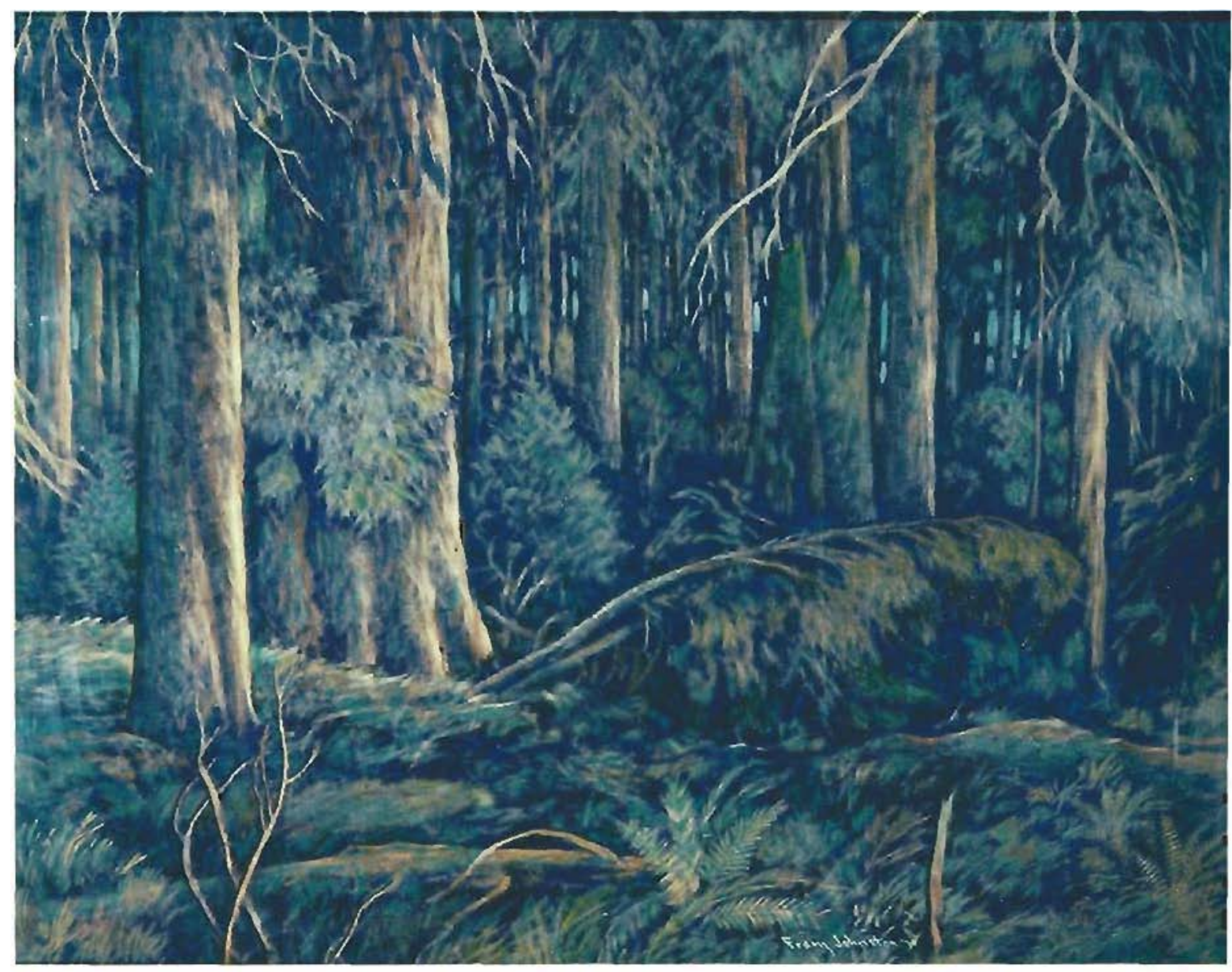

Alow:

FRANZ IOHNSTON

$1888-1949$

Fons therior. 1930

vil on canvas

$76.2 \times 101.6 \mathrm{~cm}$

signed lower tight:

FRANT, JOHNSTON'30

purchased 1964

66.010
Facing pagk:

FRANZ JOHNSION

$1888-1949$

Mornenin Landereps. 1922

(cinpera, 9$) .1 \times 73.7 \mathrm{~cm}$

signed lower right:

Fiase H./polonsan

purchased Blair laing

Toronto 1962

65.018 


\section{Sidney Dawes and the McGill Museum of Canadian Art}

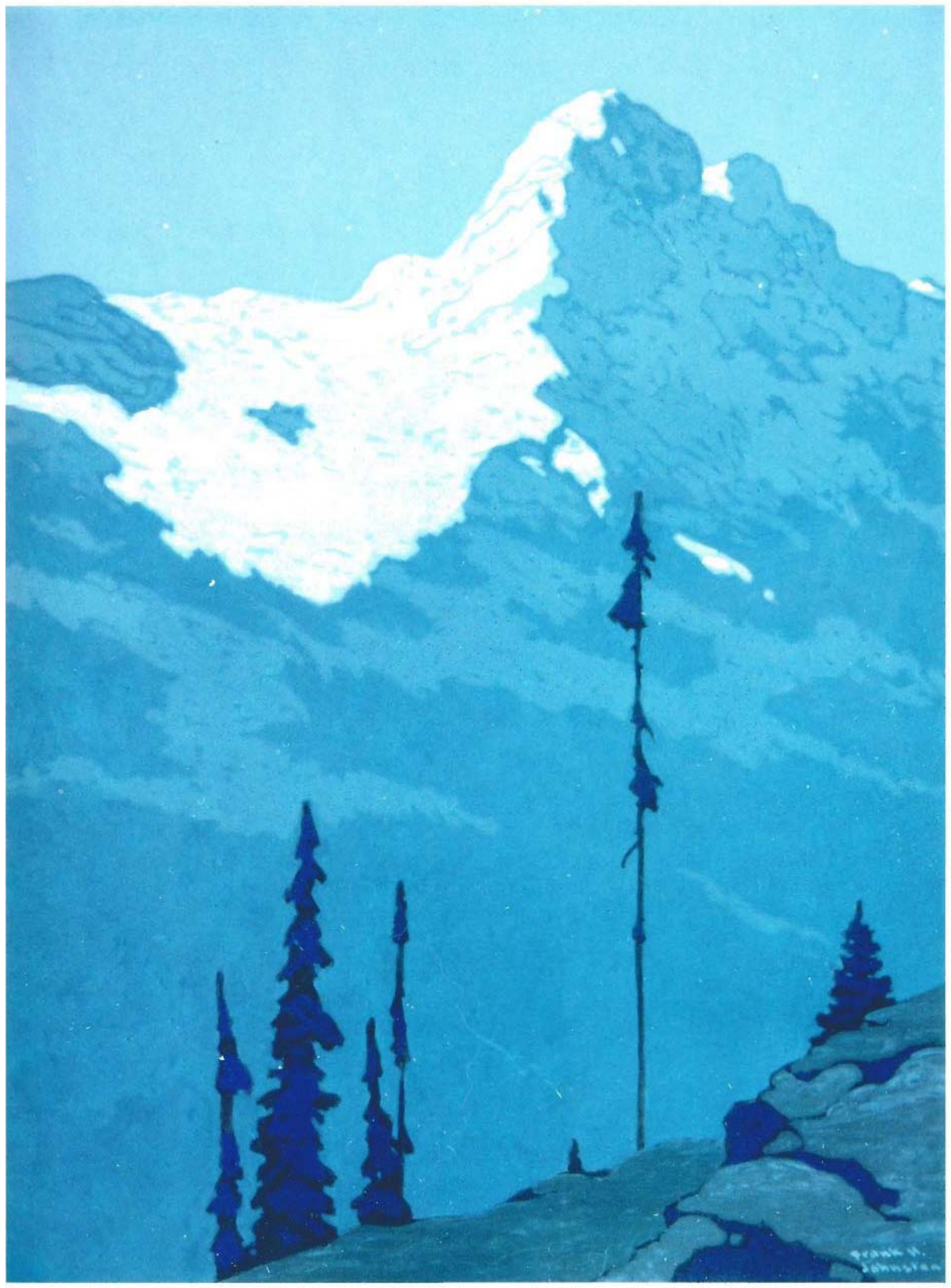


Sidney Dawes and the McGill Museum of Canadian Art

CORNFLIUS KRIL: (HHOFF. 1815-1872

Reuming Home, Lake Memphimanegng, 1863

sil on canvas

$33.0 \times 45.7 \mathrm{~cm}$

signed lower right:

C. KricghofflQucler

purchased from Kennerh 1:. 1):twes 196,3

64.001

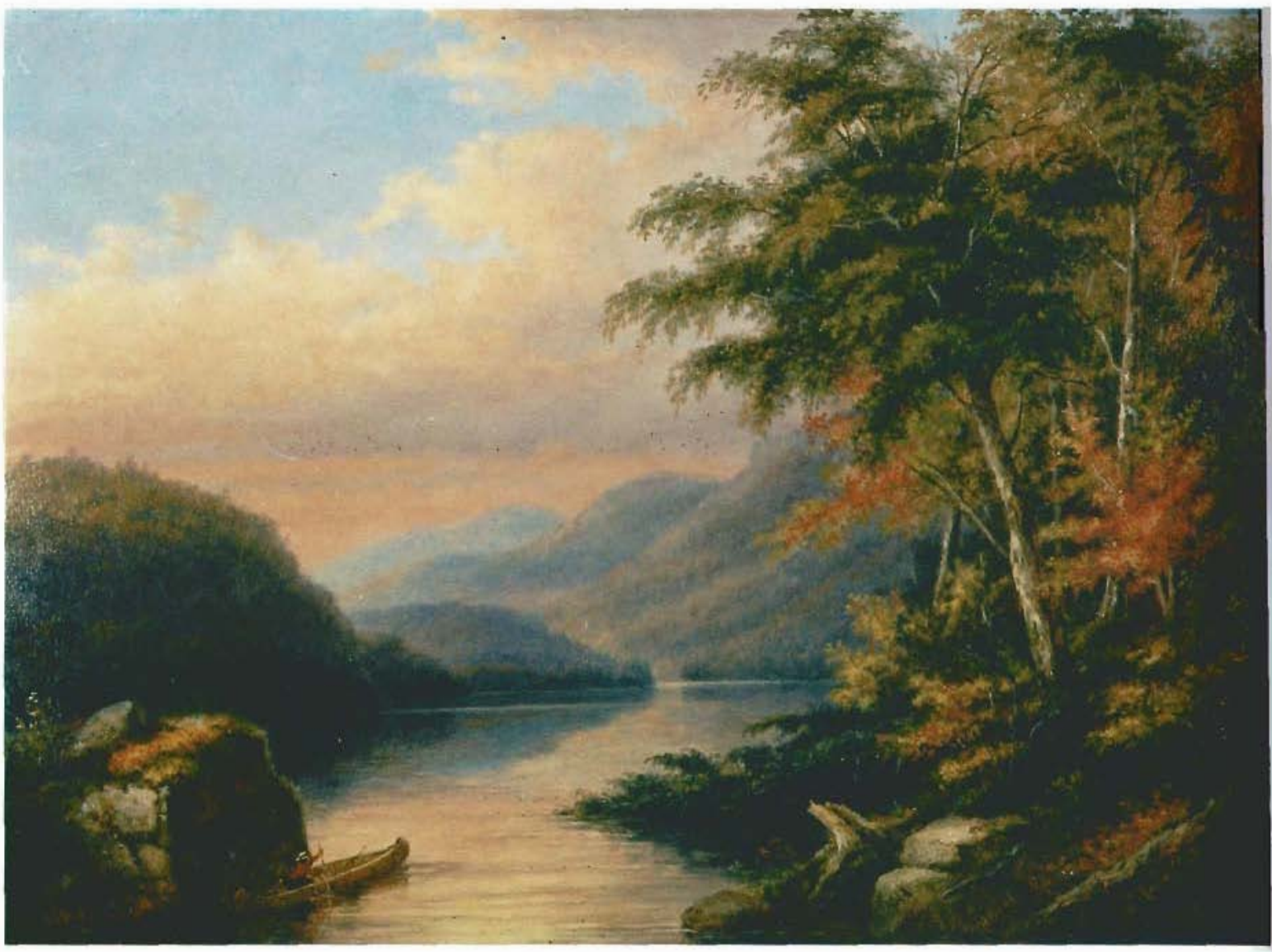

Dawes wrote to l'owell (2 Mary 1963), "This Kricghoff was in my farlect's unde's living room when my brorher Kennerh and $/$ used wo go rhere for lunch every 'Thursday, at which tims I was about 8 which would make is 1896 .

As the old uncle, whe wore sidchurns, was a pillar of the Presbyerian Church and controlled rhe lengeh of the sermon by banging his srick on the floor when it was time to stop, I am sure that he would have purchised the Kricghoff. which is signed and dared 1863, from a dealer or the arrist soon affer that Jate.

As this painting had becn in our family probably ceer since it was painted and as 1863 was the last ycar that Kricghoff painted at Lake Mempliramagog. in my opinton there is no doubt is to its auchenticity." 
Sidney Dawes and the McGill Musenm of Cianadian Art

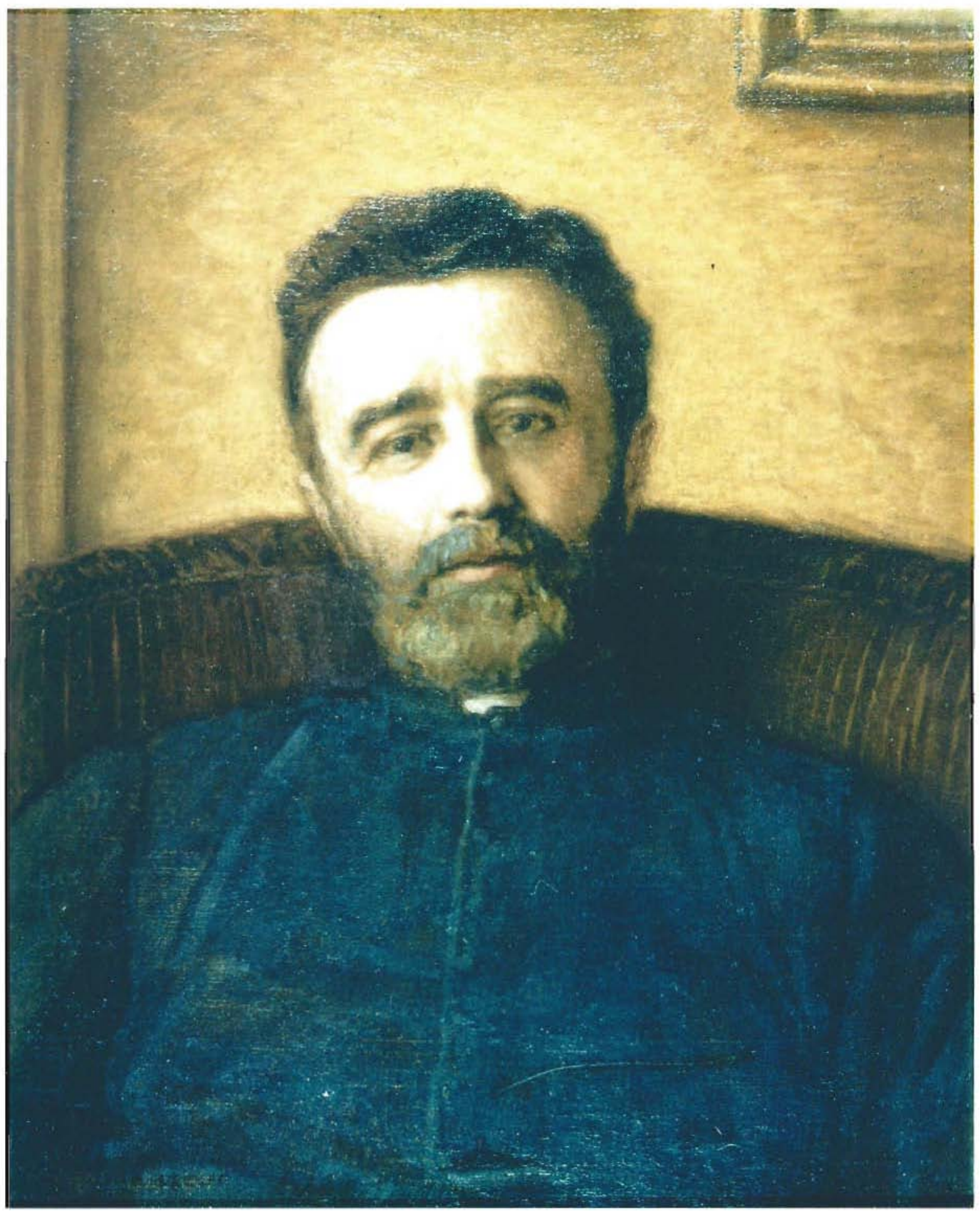

()).IAS 1.1.DUC:. 1864-1955

Monsiem l. Abbre Vincoitt ca 1906

oil on canvas, $55.8 \times 45.7 \mathrm{~cm}$

purchasced 196.3

$(1.3 .004$ 
Sidney Danves and the McGill Muserm of Canudian Art

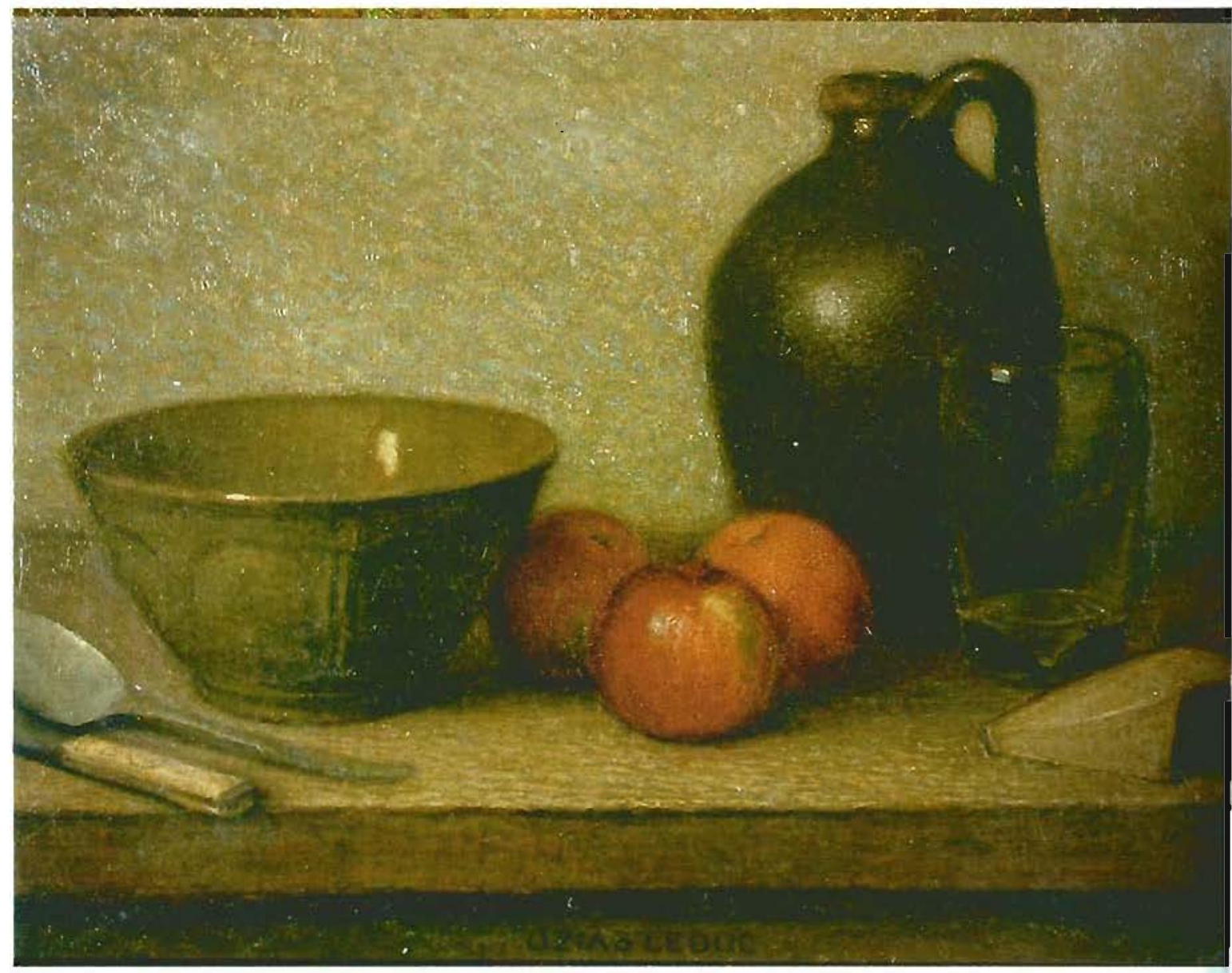

O7.1AS I FI)U:

$186+1055$

Sull lifa 1913

dil on canvas

$30.5 \times 90.6 \mathrm{~cm}$

signed luiver ceucre

OLIAS I.FISLIC:

purahiaced 1963

63.012 

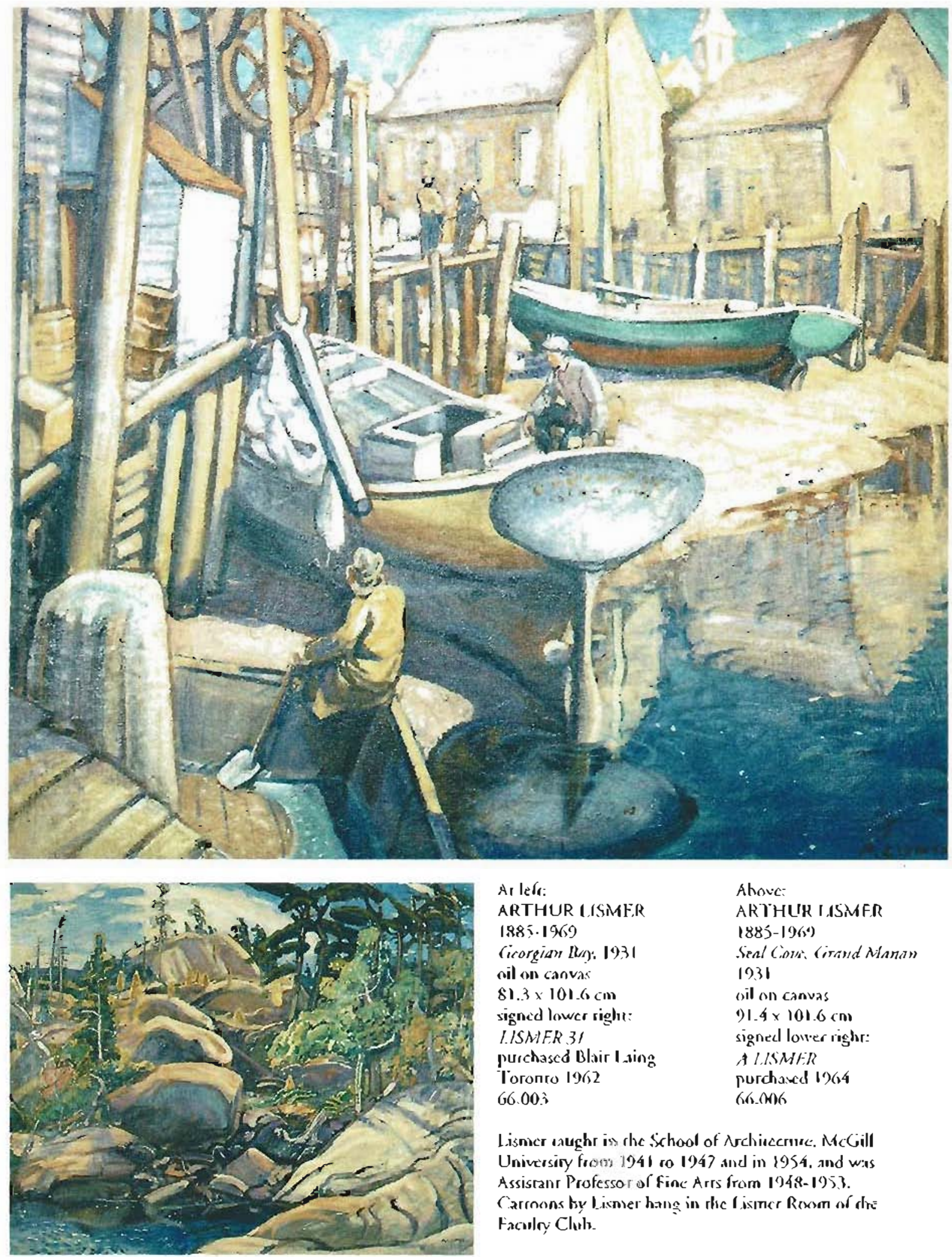

Ar lefra:

ARTHUR I ISMER

1885.1969

(icorgian $[\mathrm{k} / \mathrm{y}): 1931$

oil on canvas

$81.3 \times 101.6 \mathrm{~cm}$

signed lower righe:

IISAIER 3 I

purchased Blair I zing

Toronco 1962

66.00 i
Ahove:

ARTHUR I ISIRER

$1885-19(4)$

Seal Coms. litand Mlanan

1931

oil on canvas

$91.4 \times 101.6 \mathrm{~cm}$

signed lower righr:

A LISM/R

purchawed 1)64

(andor)

Lismer aughr in rhe School of Nehiecernec. Mc Gill Universiry frow 1941 ro 1947 and in 1954, and was Assisranr Professor of Finc Arrs from 1948-1953.

Carronos by liswer hang in the lisince Rowm of dre Faciolo Clurls. 
Sidney Dawes and the McGill Museum of Canadian Art
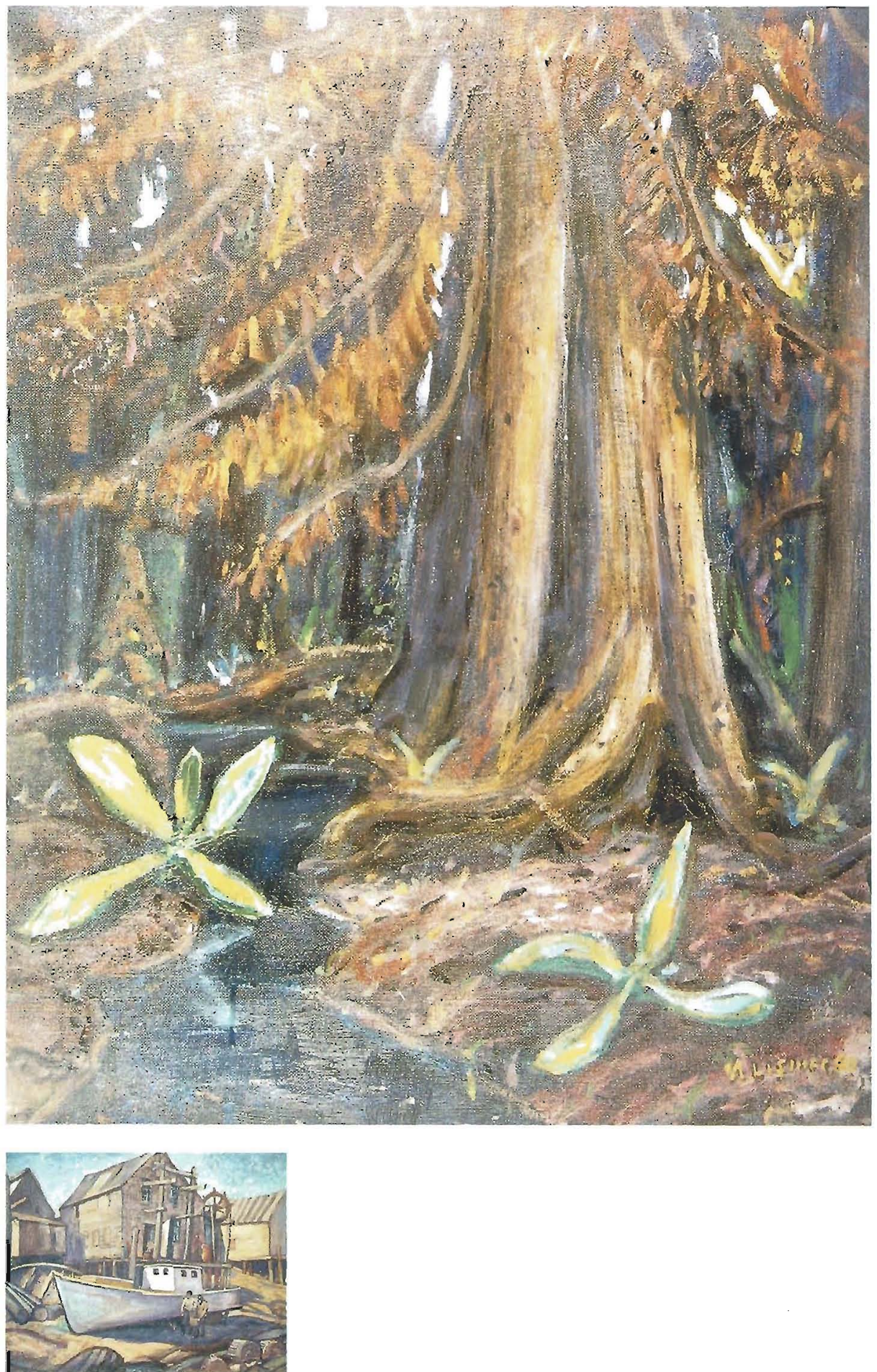
Sidney Dawes and the McGill Museum of Canadian Art

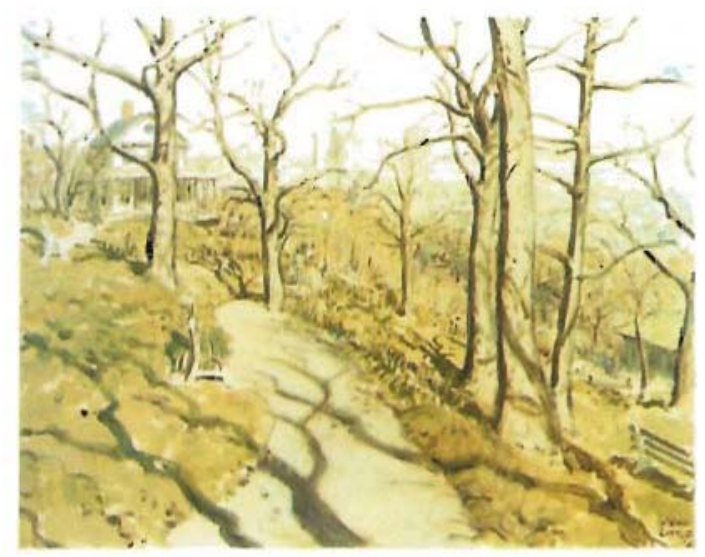

IOH L.INT'1.F, 1928-

Pat below W'estmount Lookout, 196,3

oil on canvas

$76.2 \times 101.6 \mathrm{~cm}$

signed lower right: John/l.imle/'(2,3

purchased Conrinental Galleries 1964

64.007

The house portrayed by little at the edge of the park is almost one hundred years old. Permission to demolish the building has been granted but it still stands today.

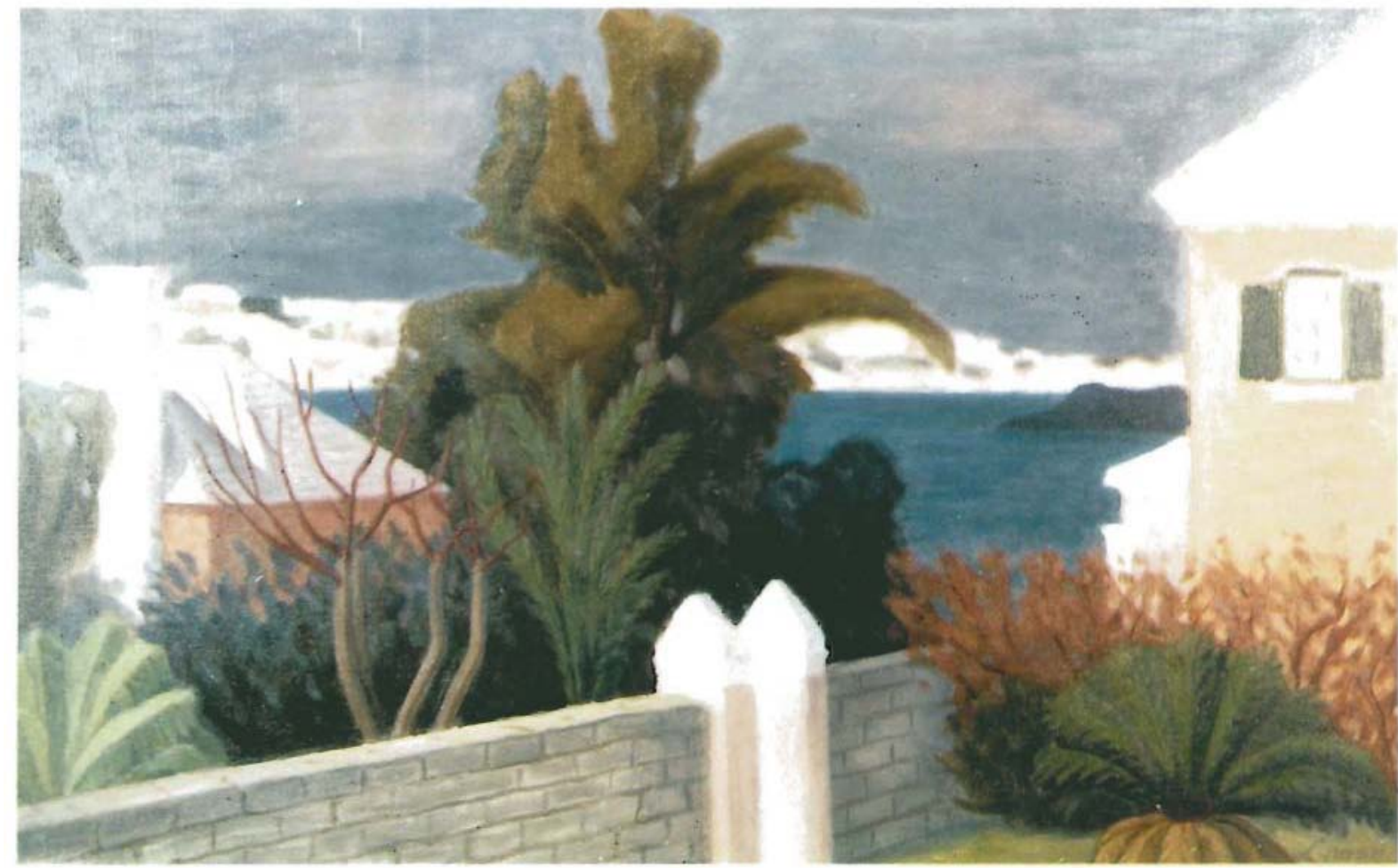

JOHN LYMAN, 1886-1967

Hamilton Harbour, Bermuda, 1958

oil on canvas, $50.8 \times 81.3 \mathrm{~cm}$

signed lower right: Lyman

purchased Dominion Galleries

Montreal 1963.3

66.014 


\section{Sidney Dawes and the McGill Museum of Canadian Art}

A4 rivbr

II II MAK: IOSONAII)

$1874-1932$

Mosat fiawhis, fevkei

1427

in lon canves

33,8 i $111,4 \mathrm{sm}$ segned ineses righe:

1.II. Alarbourid

Therchesed Mair Laing

tarame 1962

6t. Den?

Dskaw:

C. MII AMI

14.57 .1917

Cavioles, tepoterwiers

$[8] 1$

watenalout

$48.2 \times 85.9$ an

agand lower hefr

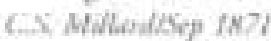

purstemed

IMominion Cidlien

Muntral 196 :

63.004
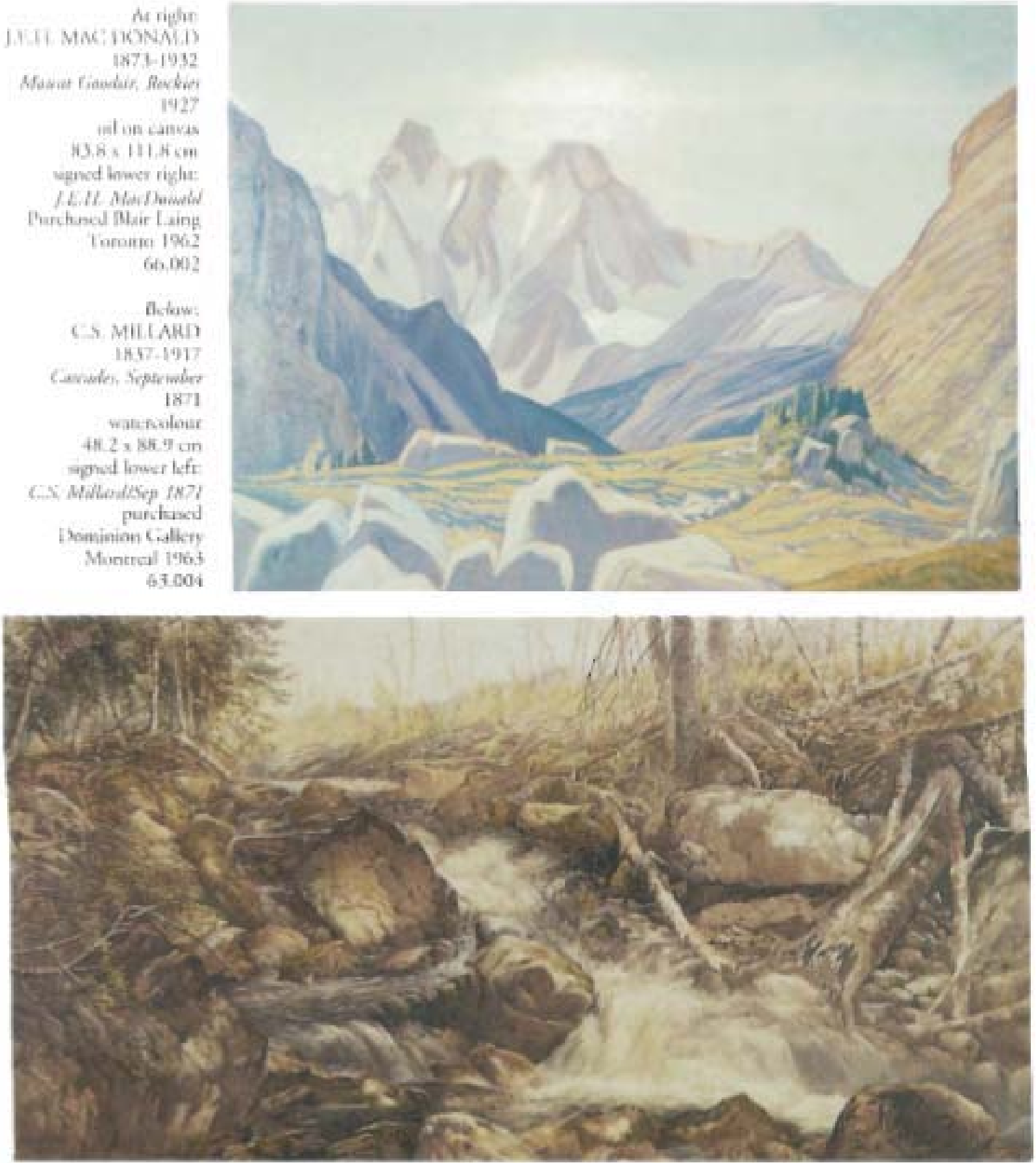
Sidney Donues and the McGill Museusn of Canadian Art

DAAUD MII.NI- 1852-195-3

Sprouge Ponl. 19)28

oil nn canvs, $30.8 \times 61.0 \mathrm{~cm}$

signed lower righr: Laril $\mathrm{MJime}$

purchaxed Blair Laing. I oronon 1\%,

63.(k) I

In 1928. Ihe vedr Sprong from/ was pained.

Milne arld hi. house near l. .ale Placid, moved

back on ranada and speut slo summer ar

b.akc l'cmagami. Omasio.

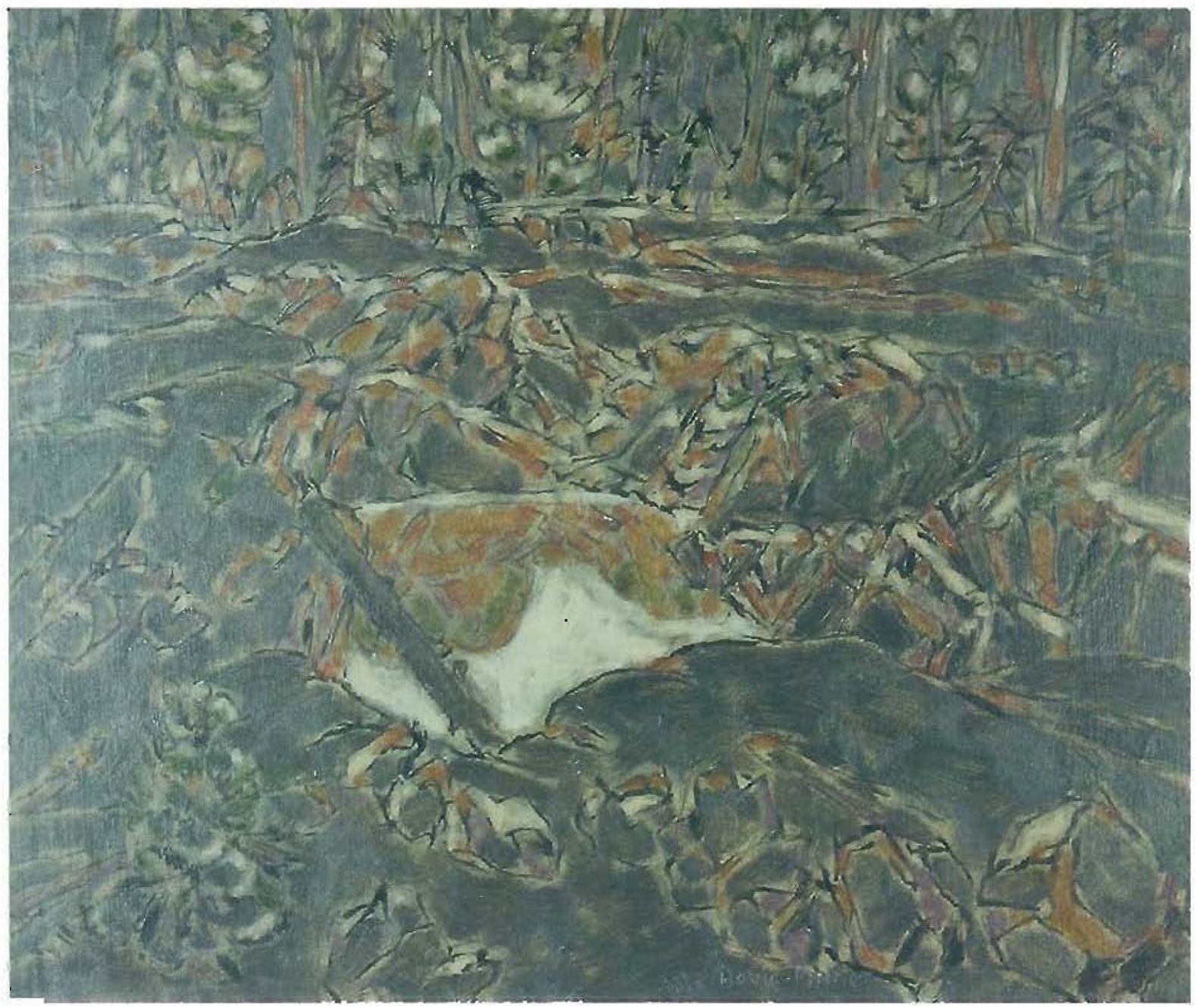


Siduey Dawes and the McGill Museum of Canadian Art

KA'THIIHN MERRLS 189.7-1986

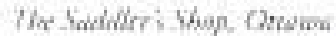
1428

nil an canvos

$35.4 \times 61.0 \mathrm{~cm}$

signed lower righte KNA Marri purchliaxd Wiltec Klinktentf Giallery. Moneresl 1969 65.007

A Menmeales, Morris lived in Octaws from 1922 to 1928 when stiv ecturned to Montreal An oil sketch of The Soditler's Shop is in a privare collection in Montreal.

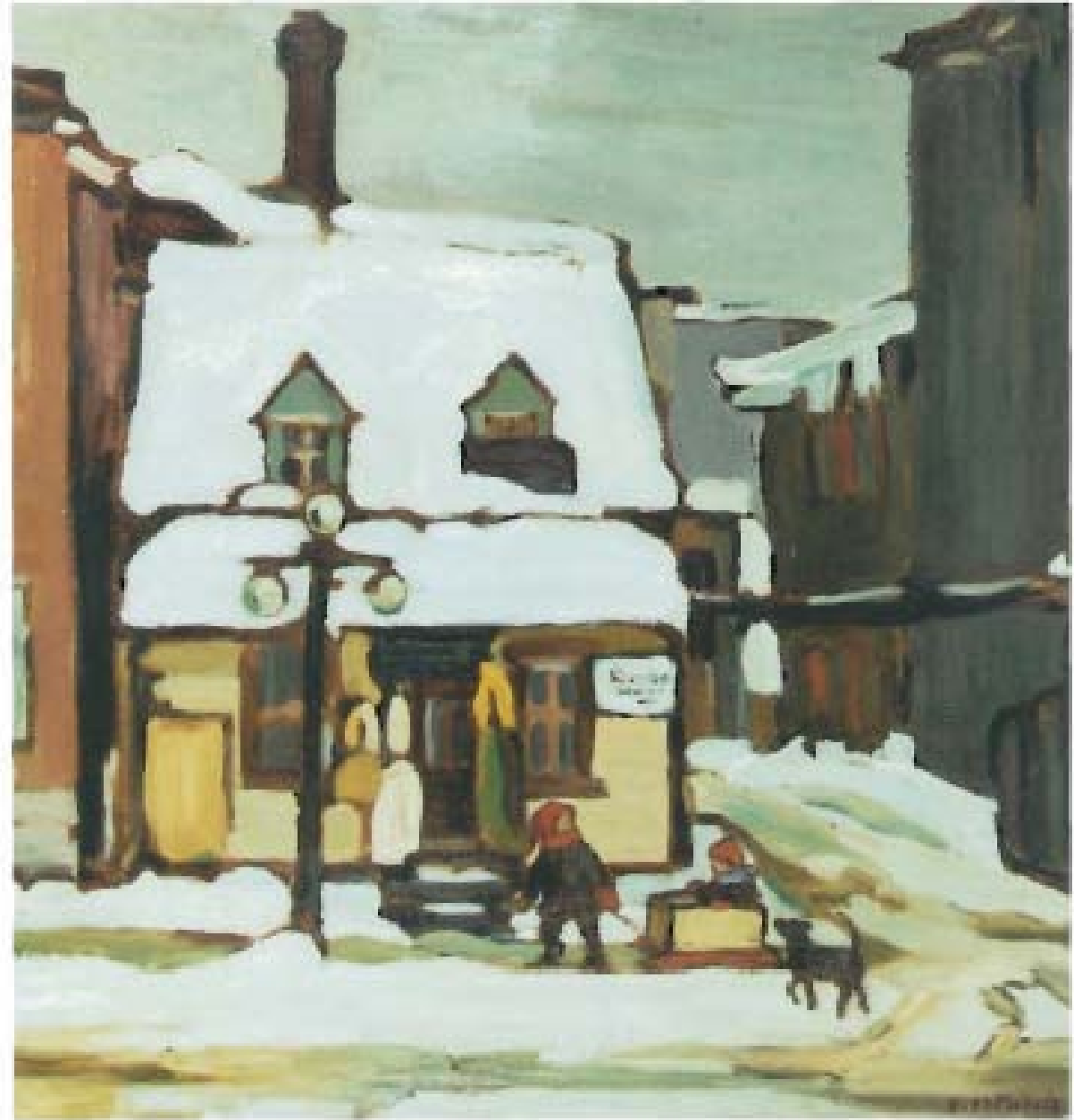


Sidney Dawes and the McGill Museum of Canadian Art
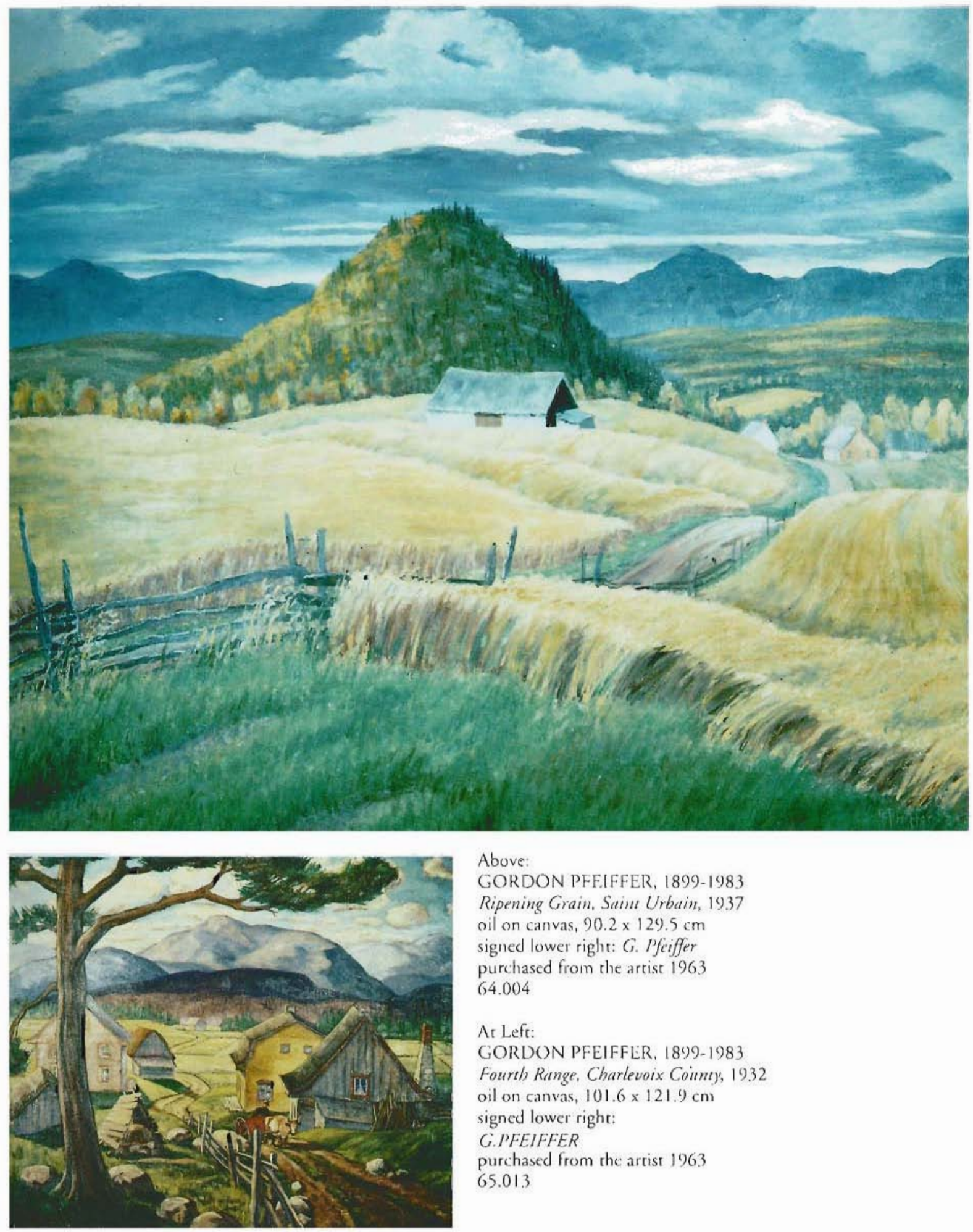

Above:

GORDON PFFIFFER, 1899-1983

Ripening Grain, Sain Urbain, 1937

sil on canvas, $90.2 \times 129.5 \mathrm{~cm}$

signed lower right: $G$. Pfeiffer

purchased from the artist 1963

64.004

At Left:

GORDON PFEIFFER, 1899-1983

Fourth Range, Charlevoix County, 19.32

oil on canvas, $101.6 \times 121.9 \mathrm{~cm}$

signed lower right:

C.PFEIFFER

purchased from the arrist 1963

65.013 
Sidney Dawes and the McGill Museum of Canadian Art

Bclow:

(JORI)ON J'FEIFFER

$1899-1983$

Laurentian lake, 1958

sil on board

$101.6 \times 121.9 \mathrm{~cm}$

signed lower lefi:

C. Pfeiffer

purchased 1964

65.016
(iORI)(ON PFFIFHER

$18909-1983$

Cose frinisy, 1934

nit un carvas

$101.6 \times 121.9 \mathrm{~cm}$

sigsed lower lefi: (i. Pfeiffer

purchased from the

arrist 1963

65.014

Aeright (iOTI) ()N PFEIFFER 1899-1983

laturentinas. Winter, 1933 oil on canvas

$91.4 \times 101.6 \mathrm{~cm}$ signed lower right Giordon F. Pfaiffer 33

65.015
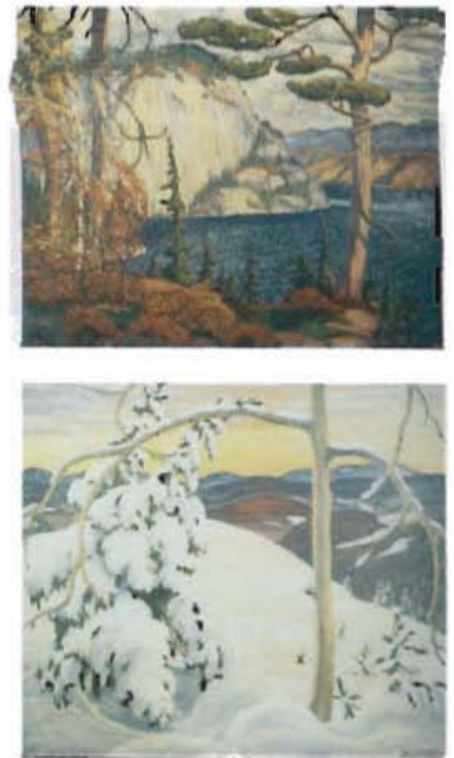

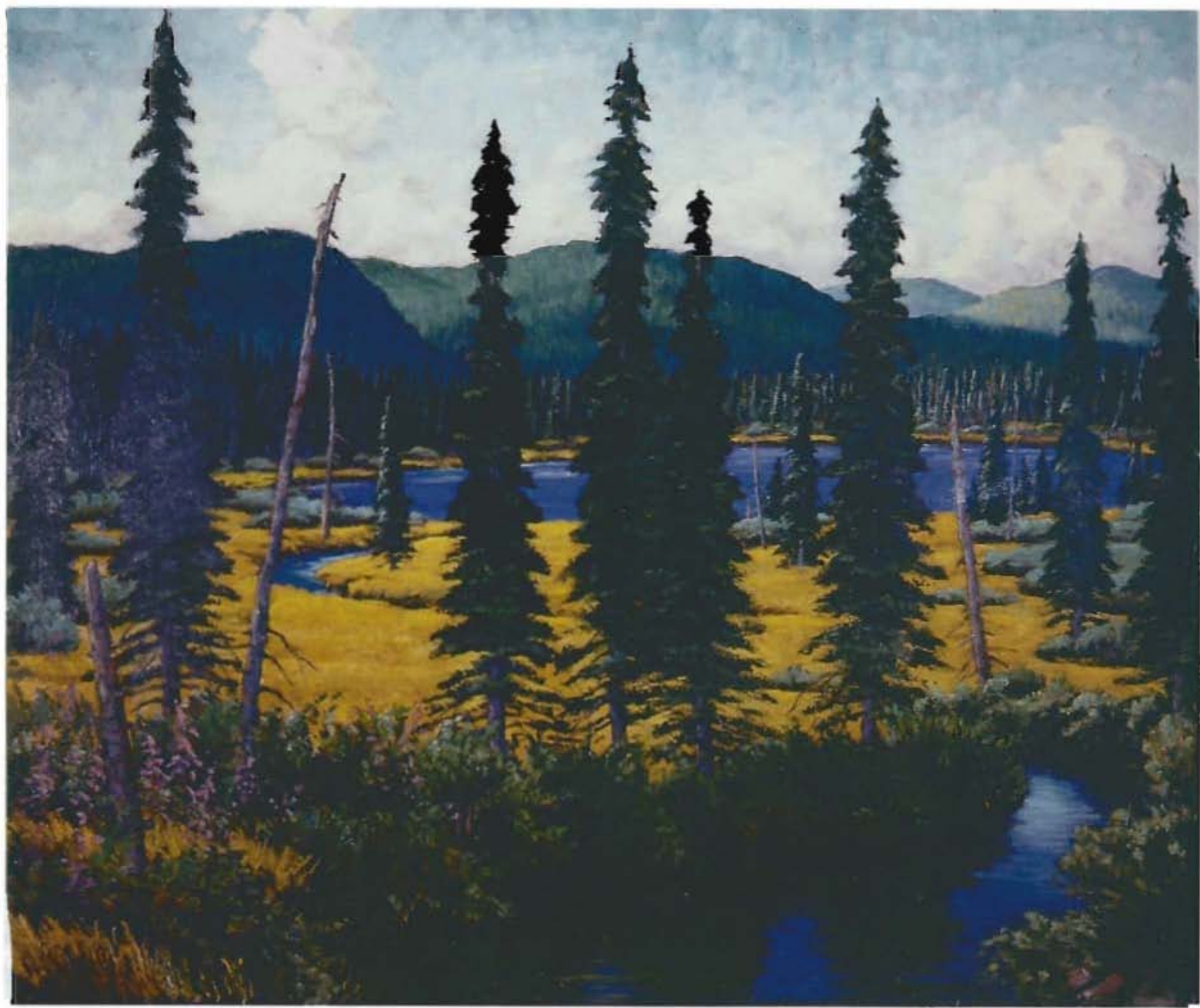


Sidrey Dawes and the McGill Mrusesun of Canadinu Arr

ROBERT PIIOT

1898.1967

Mosru Misiry from

Poinse 14 P'ic, 1962

oil on canu'ss, $60.0 \times 88.9 \mathrm{~cm}$

signed lowes rivlur: $R$ P/LOT

6.5 .003

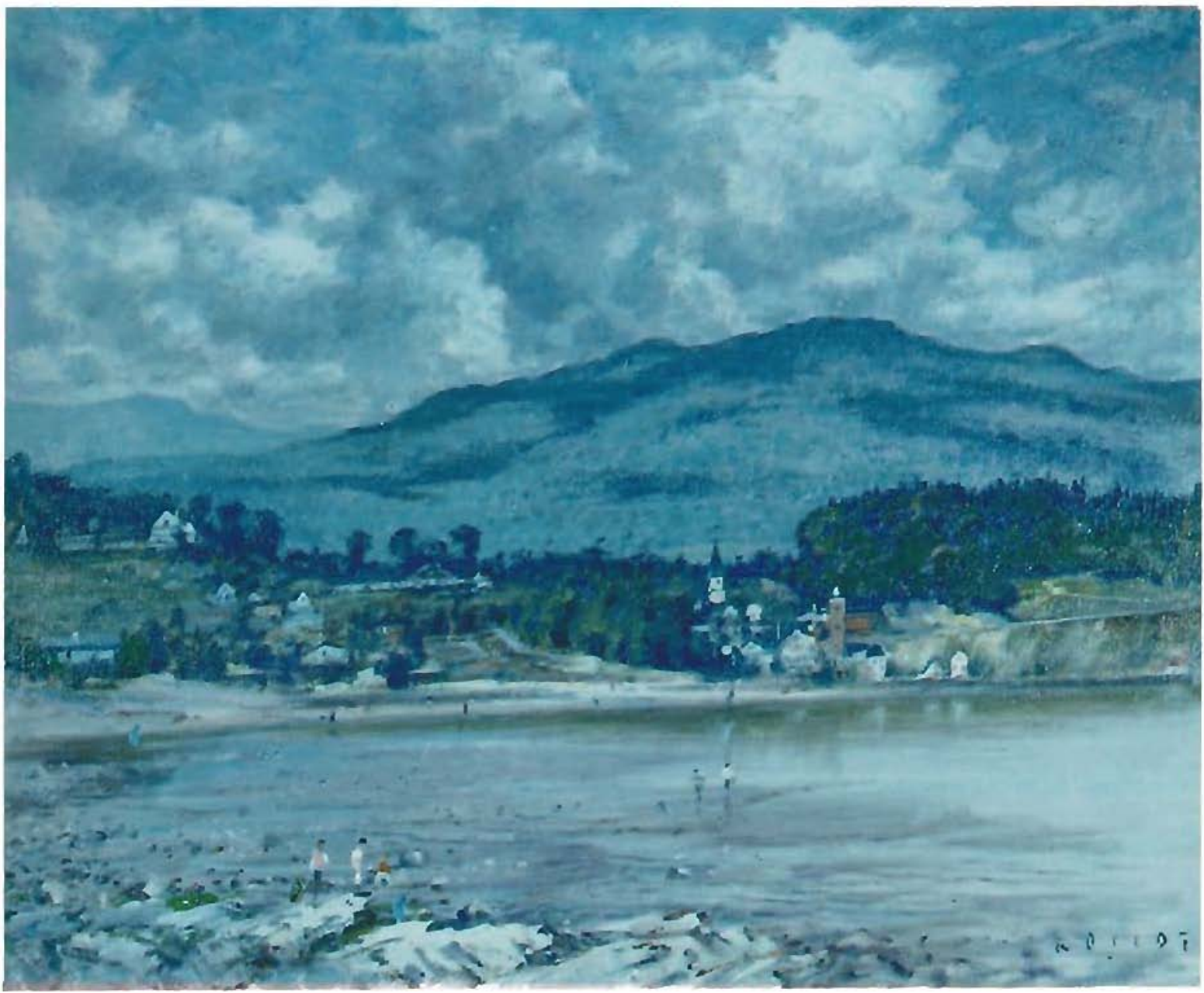


Sidney Dawes and the McGill Museum of Canadian Art

\author{
ROBERT PILOT, 1898-1967 Pilor, the stepson of Maurice Cullen, \\ The Ramparts, 1949 was married to Dawes' niece. \\ oil on canvas $\mathrm{Hc}$ and Dawes were friends and \\ $61.0 \times 81.3 \mathrm{~cm}$ travelled rogecher. Pilor often visired \\ signed lower right: the Dawes at Murray Bay. Many \\ RPILOT 49 of Pilot's paintings were painted in \\ purchased 1965 the Quebec and Lower \\ 66.025 St. Lawrence region.
}

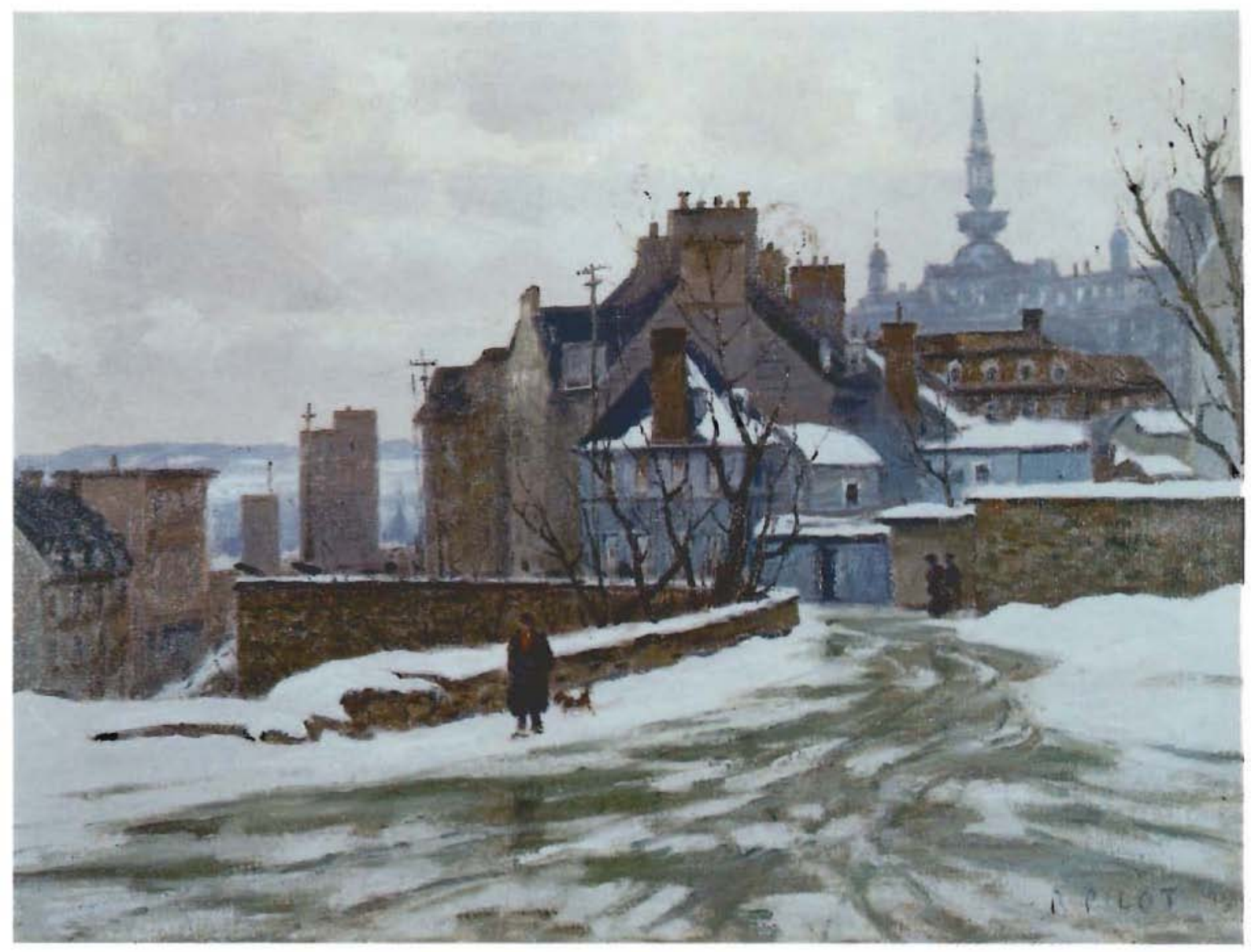




\section{Sidney Dawes and the McGill Museum of Canadian Art}

ROBLRT PILOT, 1898-1967

The Basilica at Tiwilight

Quebec City

1961

oil on canvas

$86.4 \times 1.37 .2 \mathrm{~cm}$

signed lower right:

R. PIIOT/6I

purchased 1964

66.013
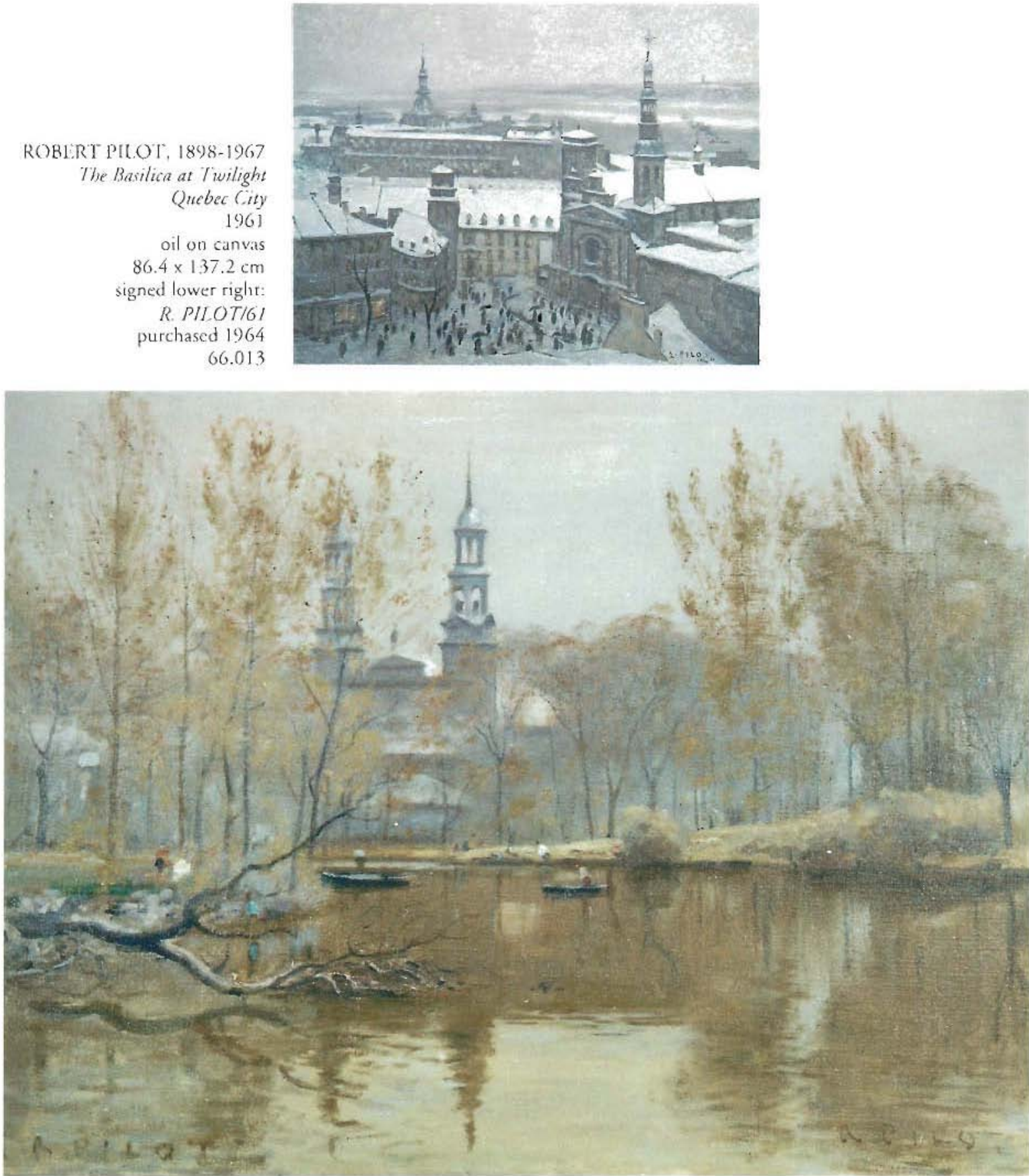

ROBERT PILOT, 1898-1967

Spring Day, St. Eustache, ca 1950

oil un canvas, $61.0 \times 81.3 \mathrm{~cm}$

signed lower left and lower right:

RPILOT

66.020 

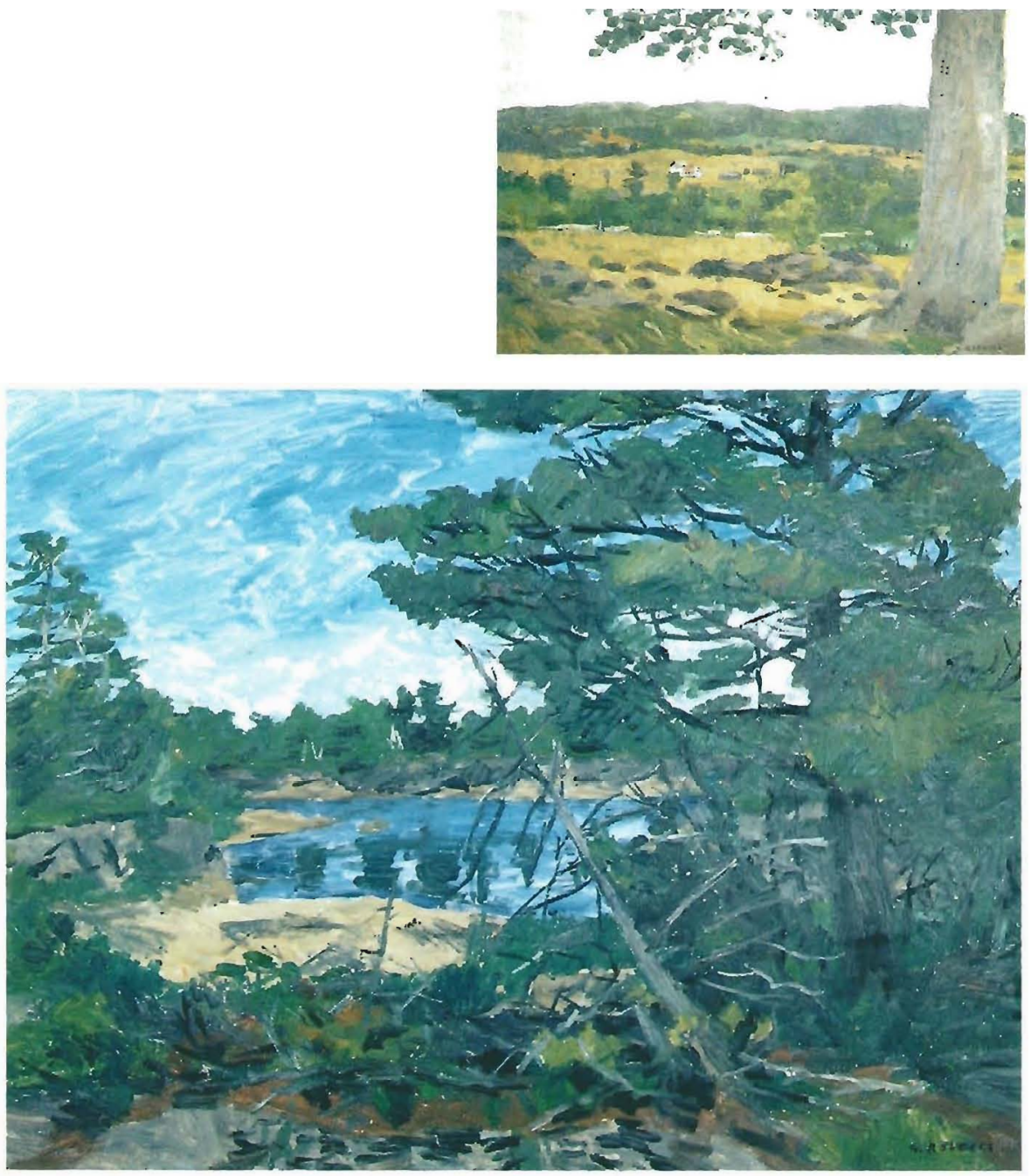

Top:

GOODRIDGE

ROBERTS, 1904-1974

Simmer Moncebello, 1956

oil on board

$61.0 \times 91.4 \mathrm{~cm}$

signed lower righe:

(i. Robests

purclrased Dominion

(iallery, Moncreal 1962

65.010

Roberts acquired a summer house wirh Affred Pinsky near Calumer, Quebec, nor far From Montcbello in 1956, the year this work was painced

Middle:

GOODRIDGF.

ROBERTS, 1904-1974

pine Free on the Shore

1962

oil un canvas

9). $4 \times 121.9 \mathrm{~cm}$ signed lower righr:

G. Roberts

65.009

Roberts spenc one month ar che farm of Professor M. Dunbar near North Harky in 1962, but ir muss have becn when he visired Point an Baril in Georgian Bay the same year thar he painced Pine Tree.

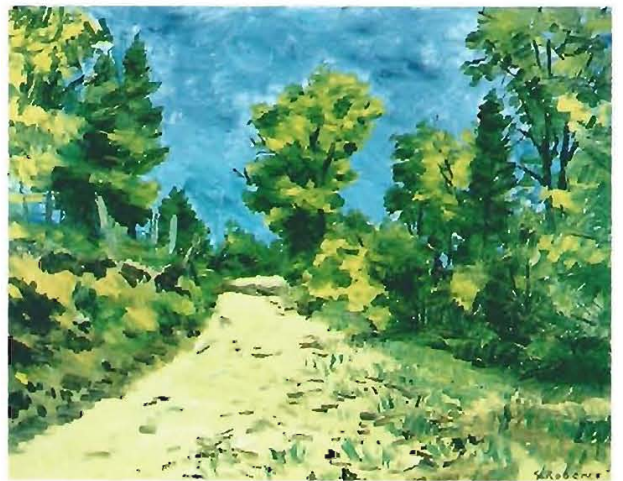

Boccom

GOODRIDGE

ROBERTS, 1904-1974

Country Roud on a

Bright Dat, 1959

oil on canvas

$71.1 \times 91.4 \mathrm{~cm}$ signed lower right: G. Roberts puichased Continental Galleries, Montreal 1964 64.005 . 
COOORISCGE ROBLERIS

1904-1974, Reclinung Nude, 1958

oil on canvas, $73.7 \times 91.4 \mathrm{~cm}$

signed lower righe: (i. Roberts

65.012

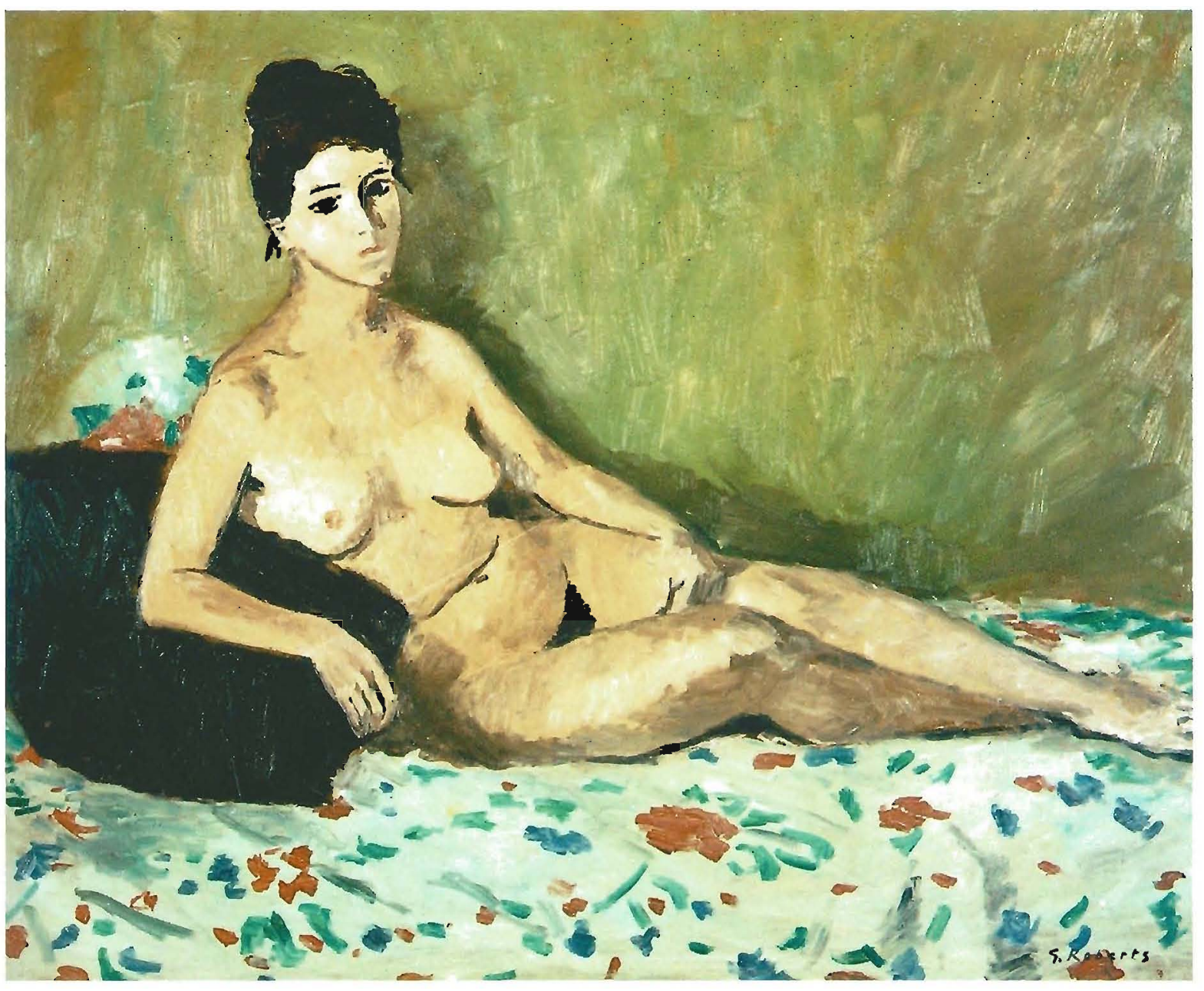

GOODRILAGE ROBERTS

1904-1974

Still L.Ife, Flowers and Finit, 1955

wil on canvas

$63.5 \times 81.3 \mathrm{~cm}$

signed lowver right:

G. Roberts

purchased Dominion Gallery

Montreal 1963

65.011

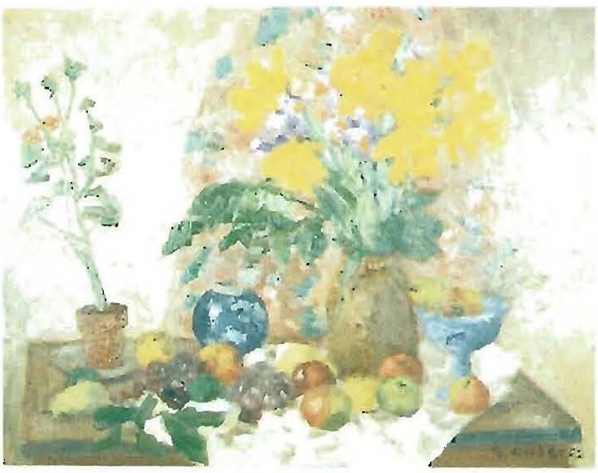


Sidney Daves and the McGill Museum of Canadian Are

(WX)NRIDKGF ROIUR'IS IOOA-197-1

Phis. Bhar Closh 1960

ail an Ganvas, $81.3 \times 81.3 \mathrm{~cm}$

signed lower right: (i. Robes:

purchesed Compincrual C...lleriser

Mlesirescl iyoús

60006

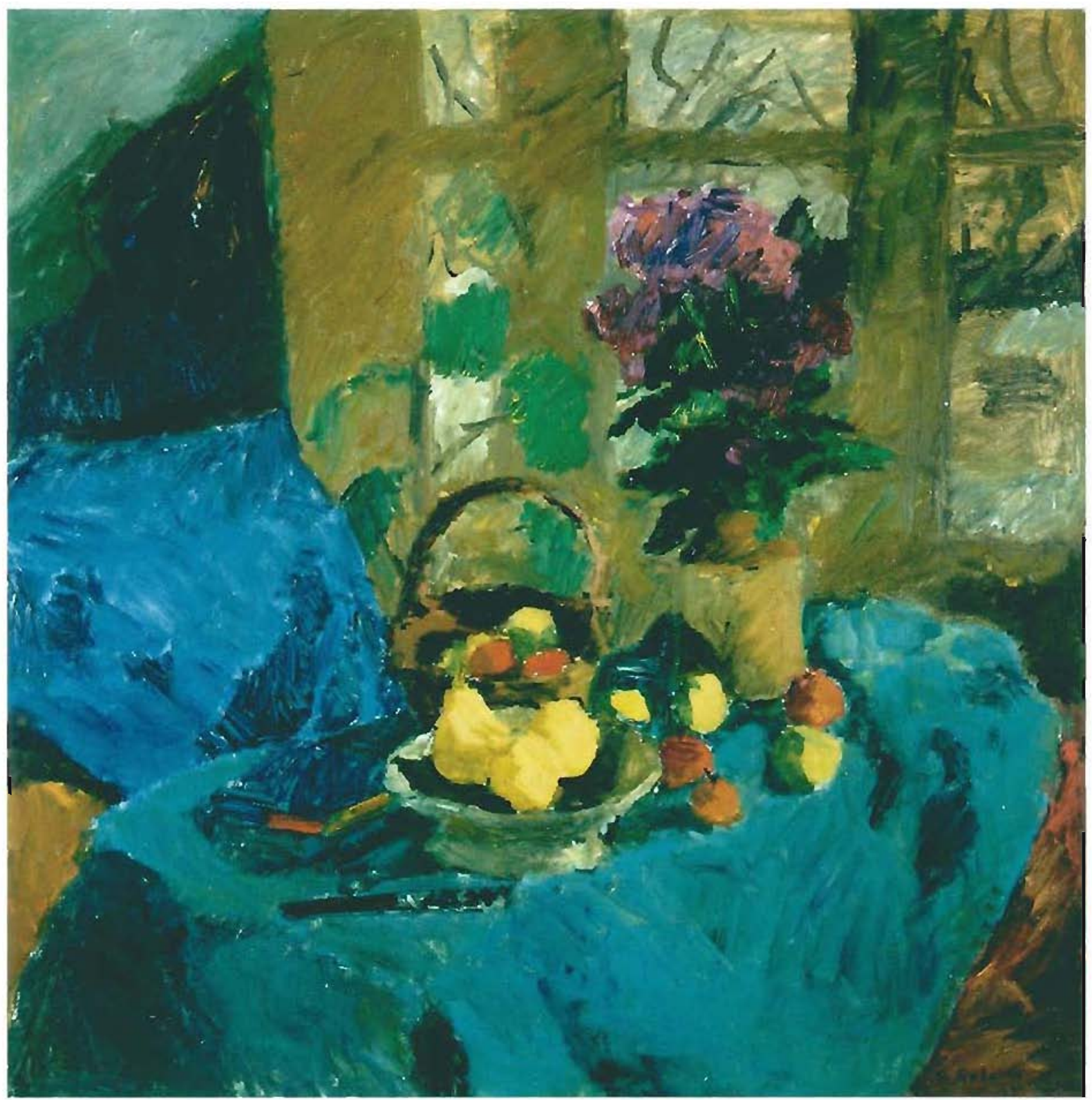


Sidney Dawes and the MeGill Musenum of Canadiun Art
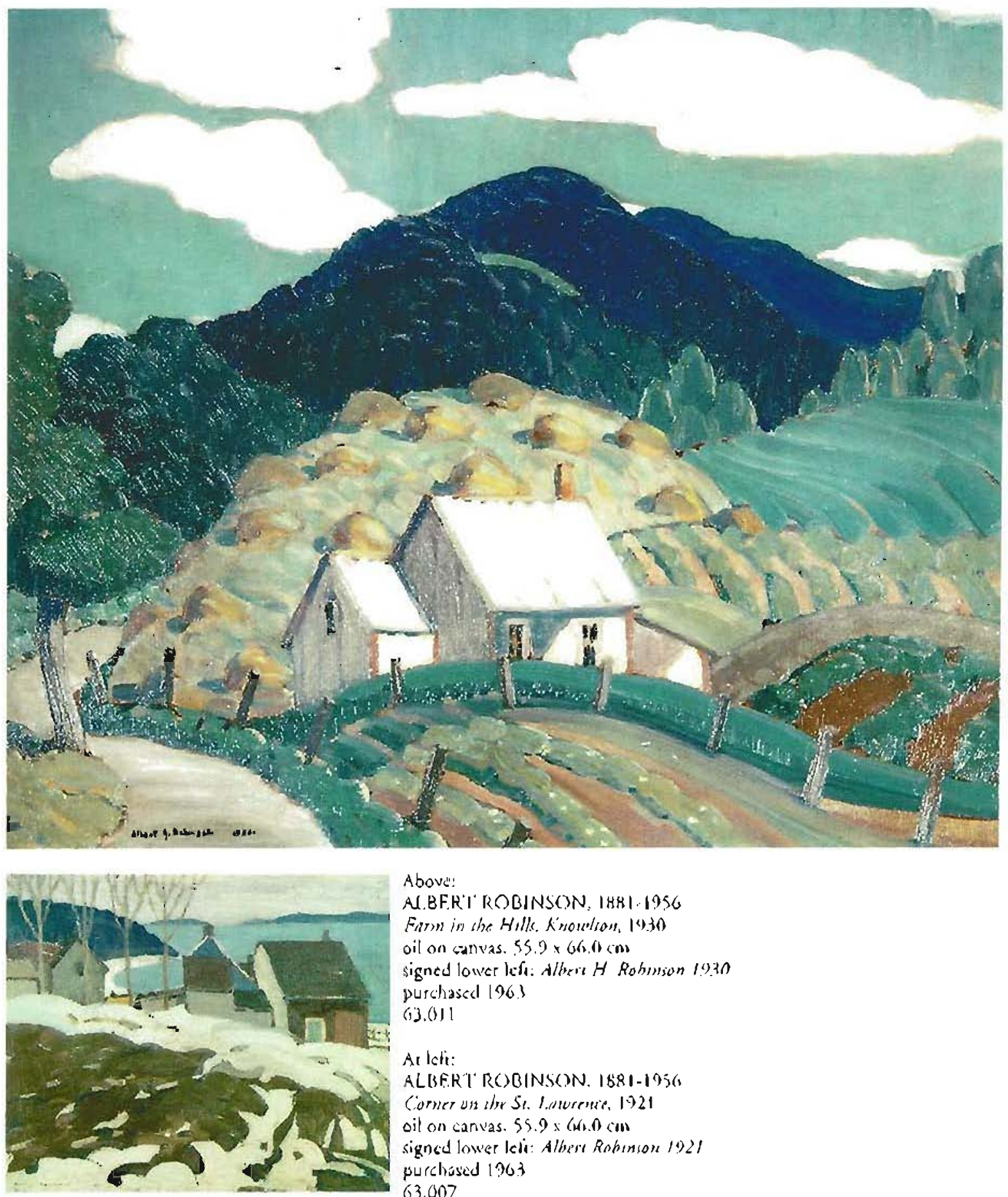

Abovs:

ALBF.R'I ROQINSON IHA1.1956

Forn in the Hille. Kiroulson, 14.30

oil on sinvas. $55.9 \times 66.0 \mathrm{~cm}$

signed lower lefi: Albria $H$ fohmson is an

purchased 1963

(i3. (3)1

Ar leti:

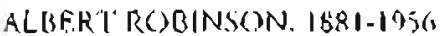

Cormer un ily $5 \%$. Inureme, 1921

dit on canvas. $55.9 \times$ (

signed lower lcli: Alower Robincon 1921

kurcliusied 1.903

63.007

Robinson zecornparucd A.Y. Jik'kwon an wiusce skerehing

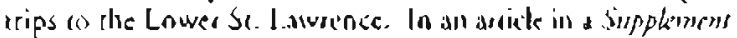

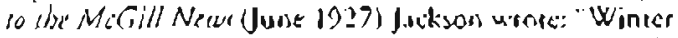

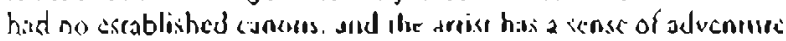

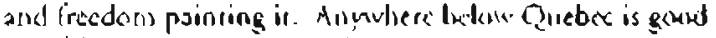
sket ching ground in winkes" 


\section{Sidney Dawes and the McGill Musum of Canadian Art}

MA SU7OK-6.07F, 1869-1937

Spring landompe, Anshathribar, 1923

oil an canyas, $41.3 \times 101.6 \mathrm{~cm}$

signied lower right

AC.A. SWOCR-COIF/I92,

pardonat ixas

66.4711

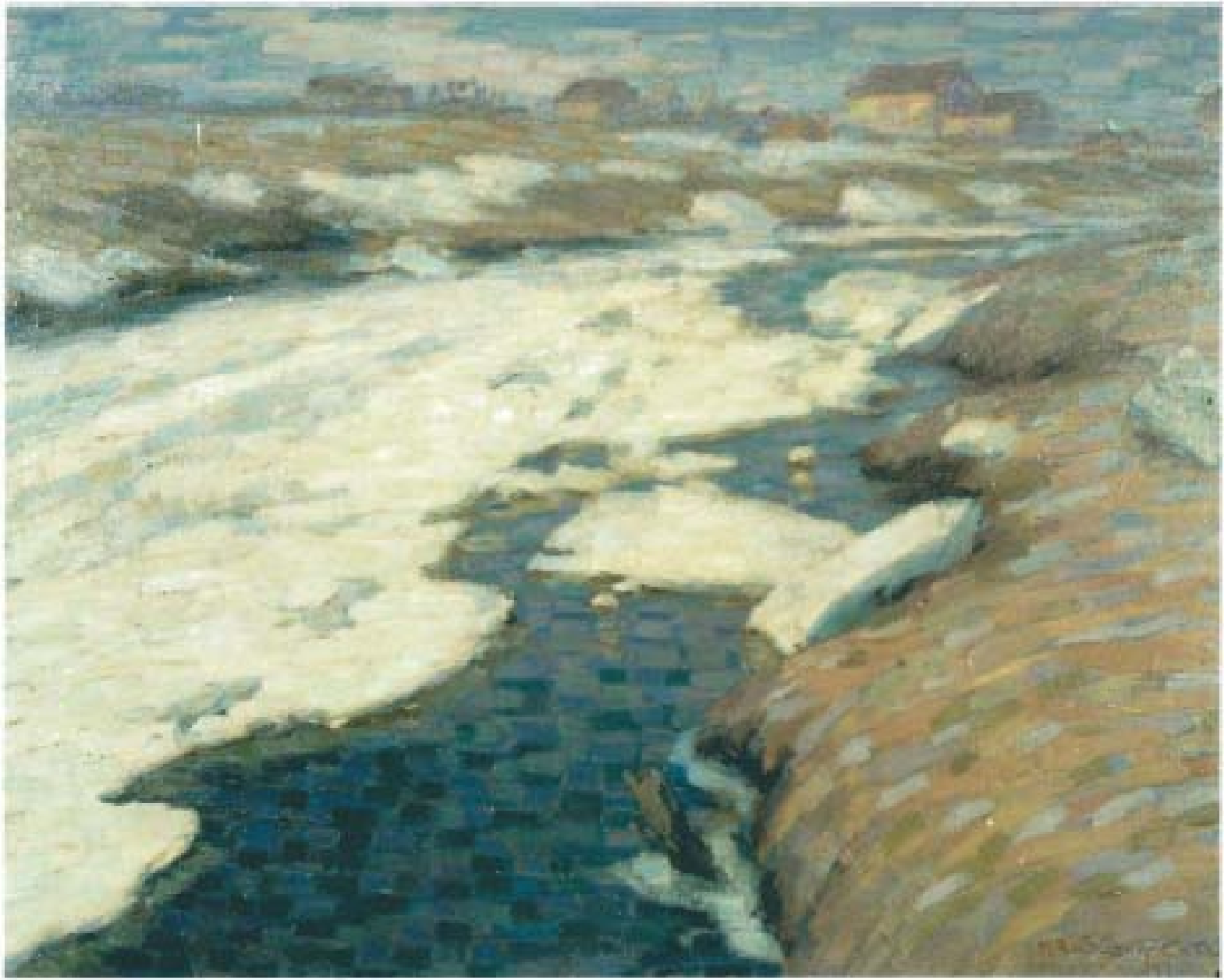

MA. SUZOR-KOTE.

1869-123?

Eartern Toumbion, ca 1908

pastel. $39.4 \times 603 \mathrm{~cm}$

signed lower nglot:

Suzw-Core

purchased Dominion

Gallery, Moomeal 1963

6.3.006

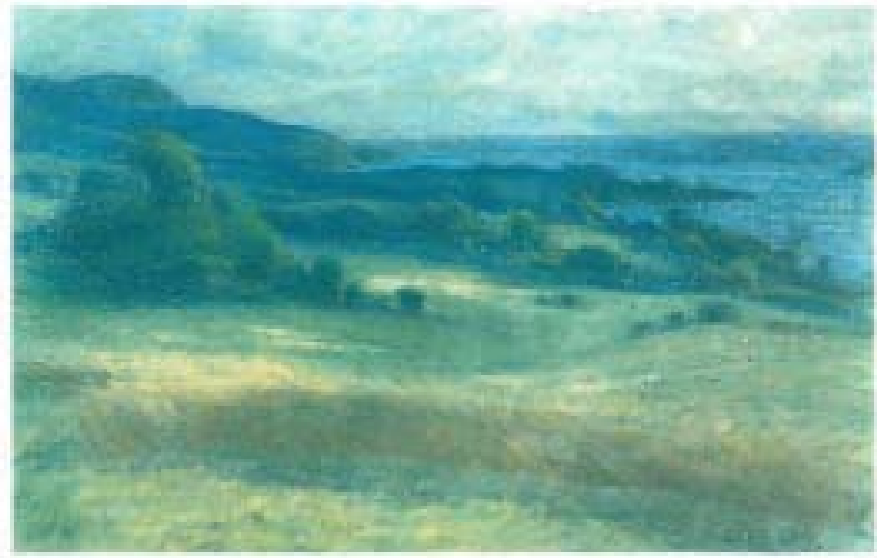




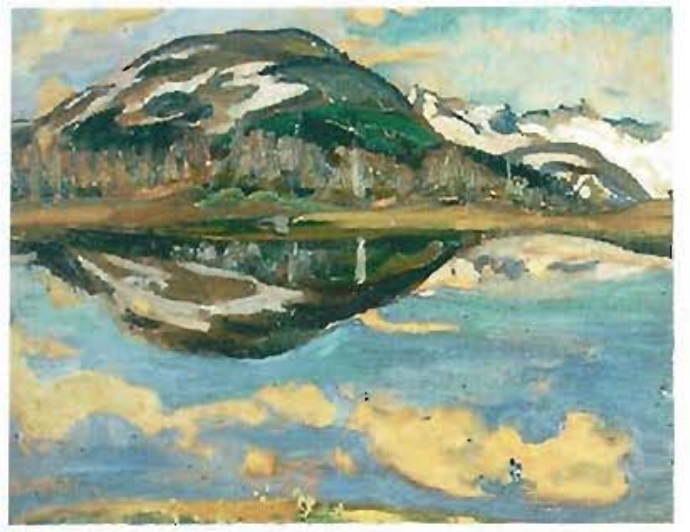

F.H. VARL.EY

1851.1969

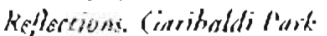

U.C., 1)?

oil on oneras

$30.4 \times 38.1 \mathrm{im}$

purchascel igrs

6,3010

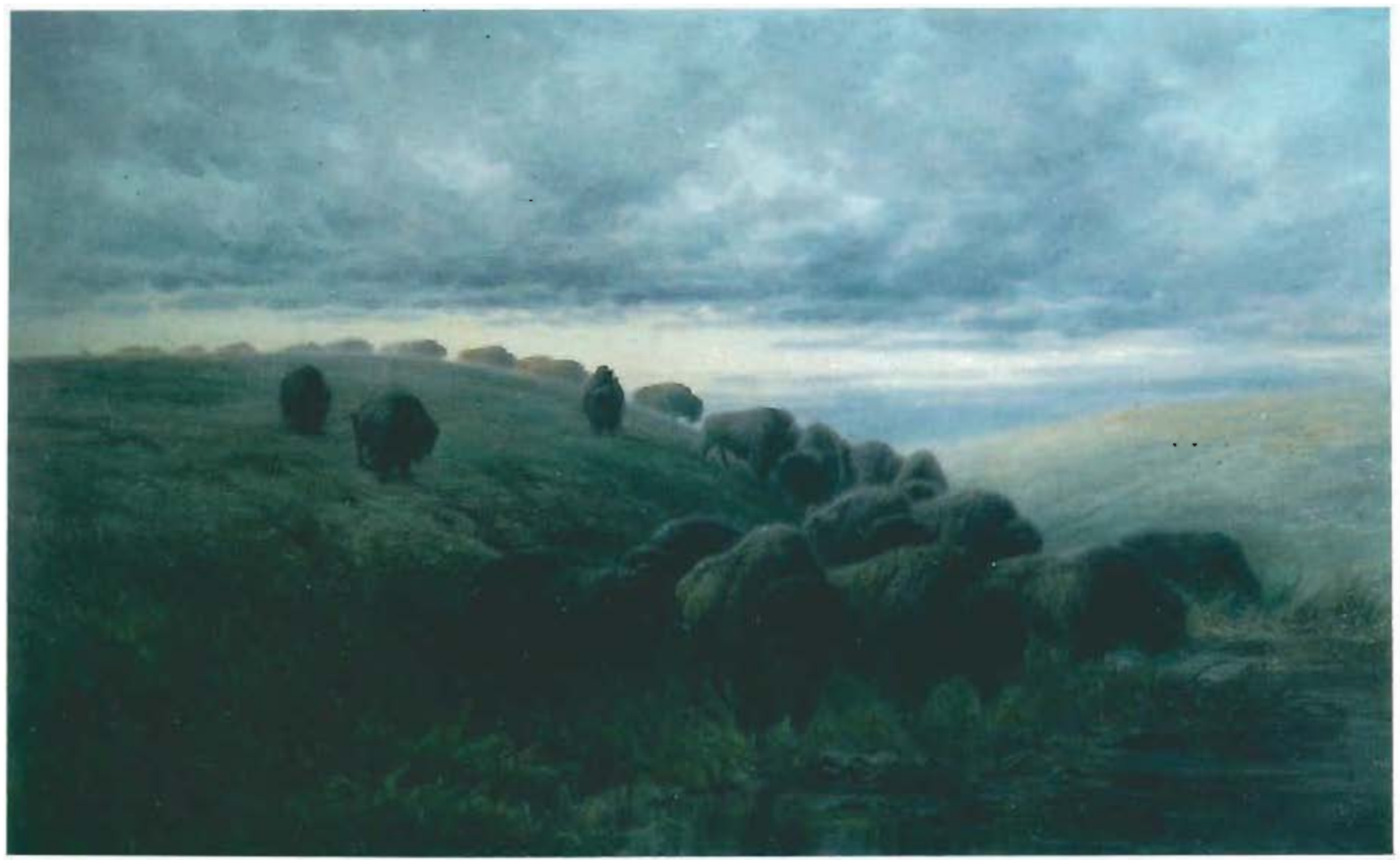

F. A. VFRNER, 18361928

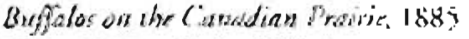

sil on canvas, $76.8 \times 127 \mathrm{~cm}$

signed lower righe: Vernerlliss

purchased Dominion Callerv

Kontreal loki2 
Sidney Dawes and the McGill Museum of Canadian Art

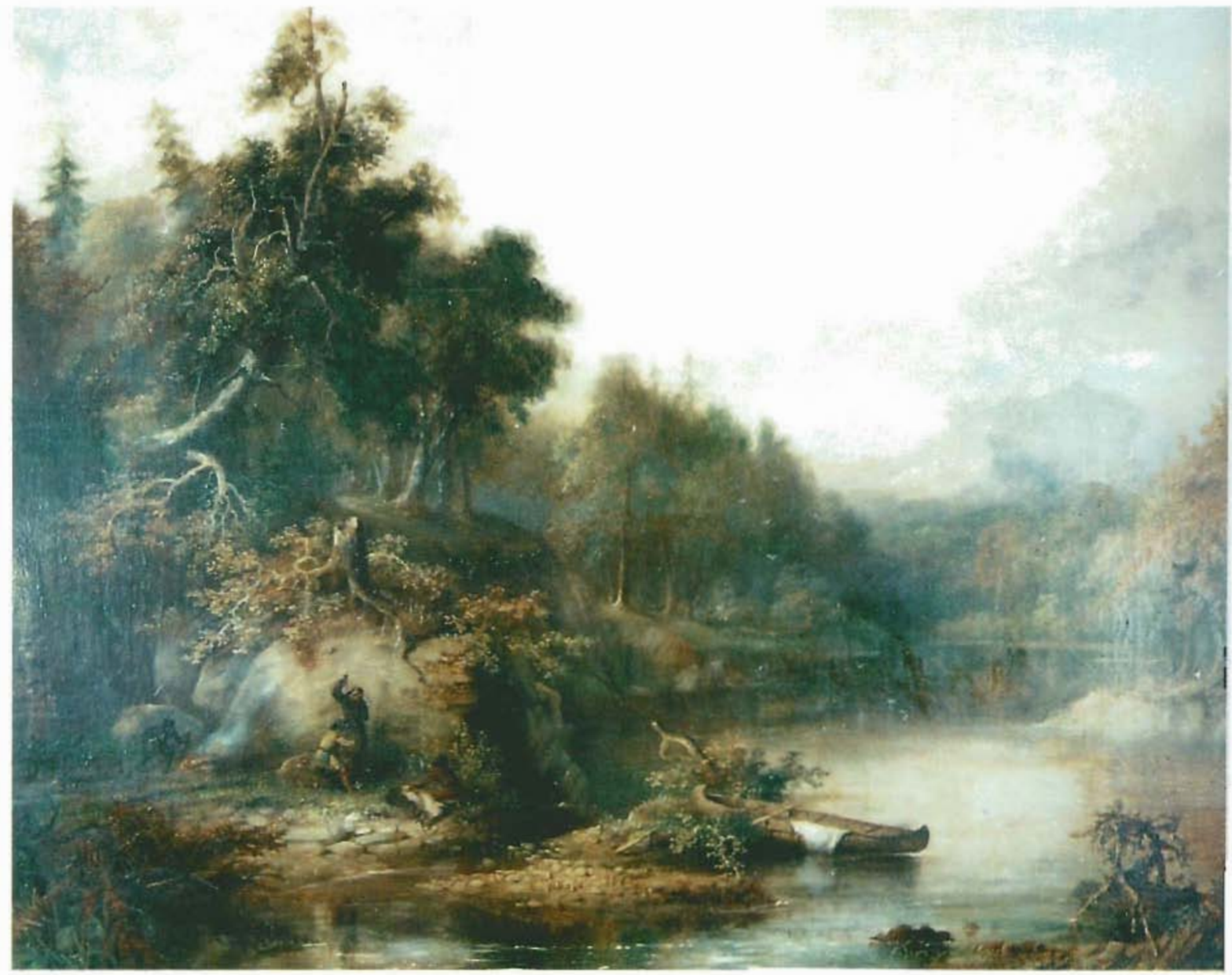

ROBERT WHAL.F, 1805-1887

Indians with Dead Caribou and Bark Canoe at Big Rock, Memphramagog, 1868

oil on canvas

$53.3 \times 68.6 \mathrm{~cm}$

signed lower centre:

R. Whale 1868

66.019 